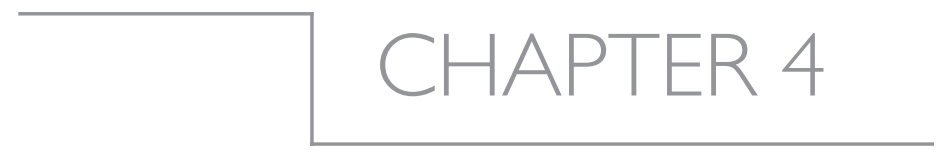

\title{
GEOLOGY, GEOMORPHOLOGY AND CLIMATE CHANGE
}

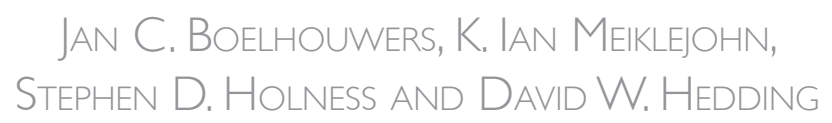

Reports from the early expeditions to the Marion and Prince Edward Islands provided the first physiographic and geological description of the islands (Van Zinderen Bakker et al. 1971; Van Zinderen Bakker 1973). The island group provides a small terrestrial environment $\left(293 \mathrm{~km}^{2}\right.$ for Marion Island and $46 \mathrm{~km}^{2}$ for Prince Edward Island) within the Southern Hemisphere midlatitudes and much initial attention was focused on the terrestrial record of Quaternary environmental change (Schalke \& Van Zinderen Bakker 1971; Hall 1978; Scott 1985). Associated geomorphological studies were exploratory and descriptive in nature, as typifies much of the geomorphological research in the sub-Antarctic (Hall 2002). Similarly, following the initial geological descriptions by Verwoerd (1971) geological studies have been sporadic on various aspects of Marion Island.

Over the past decade several studies have established a new focus on the geomorphological dynamics of Marion Island, its record of Late Quaternary environmental change and geological evolution. Here, we synthesize these recent findings and re-evaluate their implications in terms of the geological and geomorphological dynamics of the island, and the sensitivity and responses of the terrestrial ecosystem to climate change. 


\section{I Geological evolution}

Marion and Prince Edward Islands are young islands that represent the peaks of Hawaiian type shield volcanoes associated with a mantle plume (McDougall et al. 2001). The islands are located in an intraplate fracture zone at the edge of the African tectonic plate, approximately $300 \mathrm{~km}$ south of the South West Indian Ridge (Mahoney et al. 1992; McDougall et al. 2001).

On both islands, older Pleistocene grey basaltic lavas, with distinct western and eastern episodes, are covered by Holocene black basaltic lava and scoria (Verwoerd 1971; Hall 1978) (Fig. 4.1). The three commonly recognised types of black lavas, pahaoehoe, aa and block lava all occur on the Prince Edward Islands (Verwoerd 1971). Surface topography, particularly of Marion Island, is visually dominated by the youngest black lavas and is said to be sectioned by radial faults along which recent eruptive centres are found in the form of scoria cones (Verwoerd 1971; Hall 1978; Verwoerd et al. 1981). Two volcanic centres for Marion Island are proposed (Verwoerd 1971; McDougall et al. 2001) (Fig. 4.1). However, three-dimensional visualisation of satellite imagery suggests that the situation may be more complex (Meiklejohn, unpublished data).

Early research indicated that Marion Island consisted of two geological units (McDougall 1971; Verwoerd 1971; Hall 1978; Verwoerd et al. 1981). The first suggested unit ages between $276 \mathrm{ka}$ and $100 \mathrm{ka}$ before present (BP) and comprises alkaline basalt lava flows with interbedded pyroclastics from two volcanic periods, as well as intercalated glacial tills, at the beginning and end of

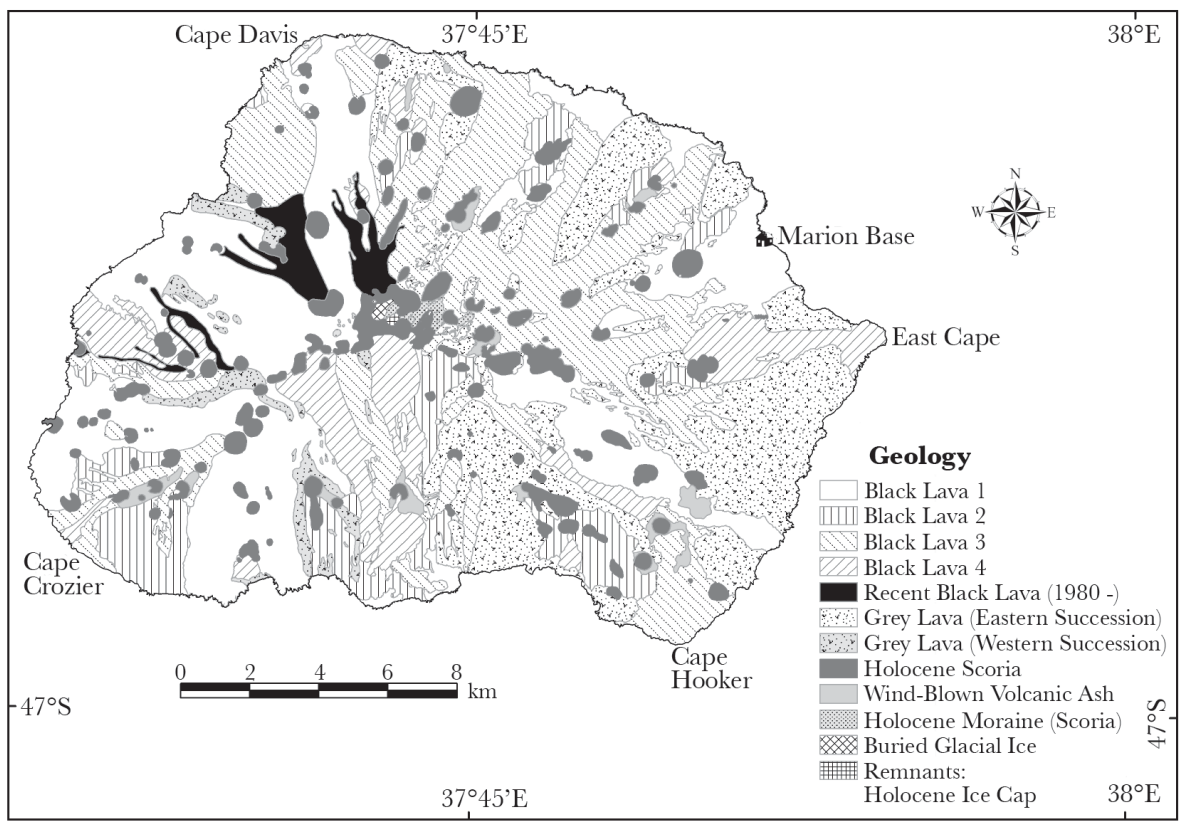

Figure 4.1 Simplified geology of Marion Island (Modified after Verwoerd 1971; Chevallier 1986; Chevallier et al. 1992; McDougal et al. 2001). 
each period. The second unit comprises black lava, over 130 scoria cones and a tuff cone on Marion Island, and at least 15 scoria cones and three tuff cones on Prince Edward Island; these were originally dated between $15 \mathrm{ka} \mathrm{BP}$ and $400 \mathrm{ka}$ BP (McDougall 1971). However, the oldest recorded dates for lavas on Marion Island have now been extended to $c .450 \mathrm{ka} \mathrm{BP}$ and indications are that the islands are less than one million years old (McDougall et al. 2001). McDougall et al. (2001) used K-Ar (potassium-argon) dating to improve the geochronological resolution and suggest more episodic volcanic activity than previously suggested, identifying eight volcanic episodes (Fig. 4.2). Recent eruptions (Verwoerd et al. 1981; Meiklejohn \& Hedding 2005) are clear indications that volcanic activity still continues. Current investigations following the recent melting of the permanent snow on Marion Island, together with Global Position Systems and aerial photography, have facilitated the updating of the original geological map (see Vewoerd 1971). This map is presented as Figure 4.1 (Hedding 2006).

Volcanism on Marion Island is suggested to have been initiated by isostatic adjustment, following deglaciation at the end of the Last Glacial Maximum (Hall 1982, 2004). This led to the contention that rapid deglaciation at the end of the Last Glacial Maximum resulted in thrust faulting of the areas that were overlaid by the thickest ice (Hall 1982). Two large topographically dominant landforms are suggested to have arisen as a result of the faulting, namely Long Ridge and the Feldmark Plateau, which are proposed as horst structures, while Santa Rosa Valley is thought to be a graben. Chevalier (1986), however, suggested that Santa Rosa Valley and other Graben-type landforms are the result of landslides that result from volcanic activity. Marion and Prince Edward Island volcanics result from regional crustal control that provides the lava from the mantle and localised edifice tectonics on the cone itself (Chevalier 1986). The possibility also exists that many of the valley landforms and scarps on Marion Island are the result of volcanic eruptions (I. Meiklejohn, unpublished data). Santa Rosa Valley and the Basalt Curtain area are not dissimilar in form to the landscape that resulted from eruptions at Mt St Helens and Montague Island (see Wunderman et al. 2004). There is a clear need to resolve the nature and age of the grey lava plateaus at Feldmark and Long Ridge to clarify the Quaternary glacial and periglacial history of these high lying surfaces and their role as possible refuge areas during Late Quaternary glacials.

\subsection{The glacial record}

Glacial reconstruction for the entire sub-Antarctic region is speculative and lacks the rigour required for accurate interpretation of former glacial conditions (Hall 2004). An evaluation of glacial extents is extremely difficult as most sub-Antarctic islands were almost entirely covered by ice during the Last Glacial Maximum and glacial margins and associated sedimentary evidence extended beyond coastal margins (Hall 2004). Of the Prince Edward Islands, only Marion Island has evidence for a glacial history and the earliest interpretations of the Quaternary glacial history are reliant on few dates and 


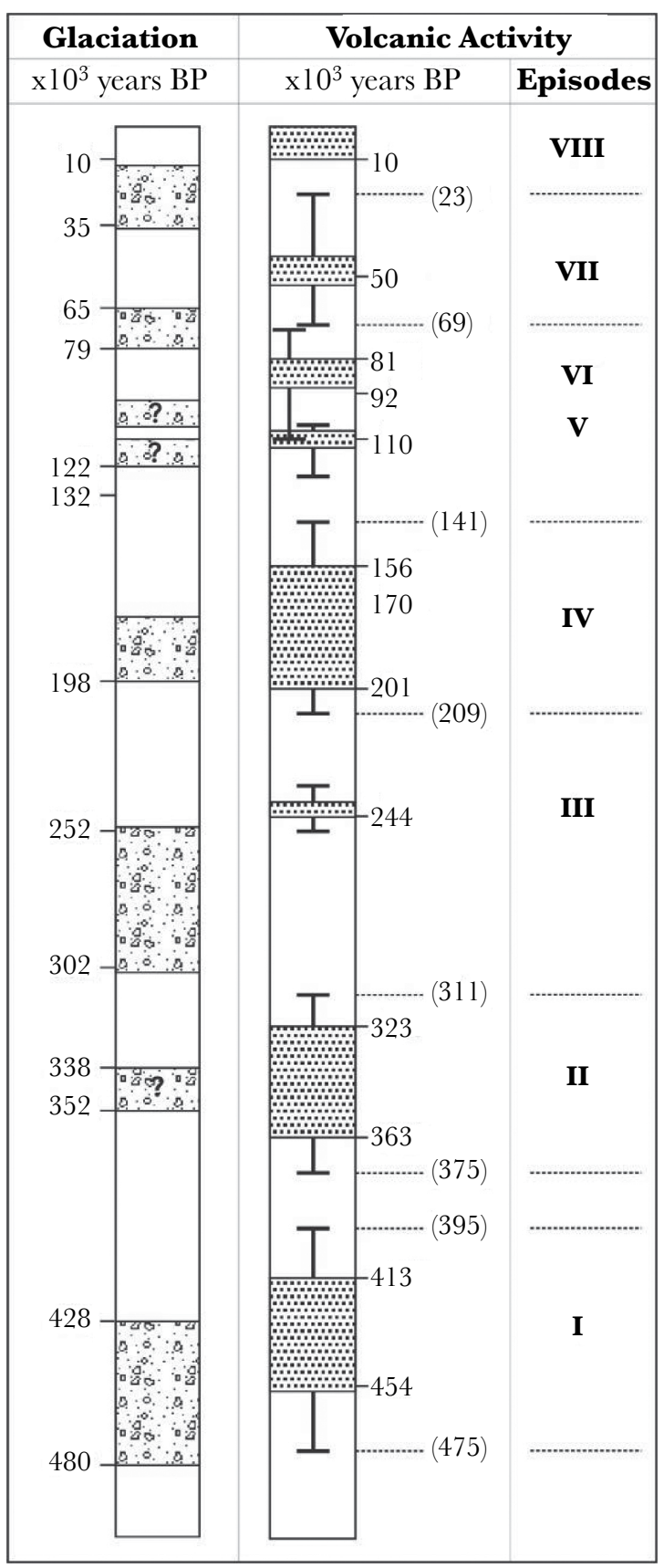

Figure 4.2 Glacial and volcanic chronology from Marion Island (After McDougall et al. 2001). 
suggested three glacial episodes that were named "Oldest", "Penultimate" and "Würm" (McDougall 1971; Hall 1978, 1982). Recent K-Ar dating of volcanic lavas has allowed improved chronological resolution of intercalated glacial tills and it is possible that Marion Island was subjected to at least five (and possibly eight) glaciations during the Quaternary (McDougall et al. 2001) (Fig. 4.2). The glacial periods dated on Marion are, within the available time resolution, contemporaneous with Northern Hemisphere Mountain Glaciation events (McDougall et al. 2001).

Deposits from the earliest glacial periods on Marion Island are covered by subsequent lava flows and are only visible in exposures along coastal cliffs, large vertical exposures, and incised stream courses (Hall 1977, 1978, 1980). Glacio-depositional and glacio-erosional features resulting from the more recent glacial episodes $(79 \mathrm{ka}-11 \mathrm{ka} \mathrm{BP})$ represent the most prominent glacial evidence on Marion Island and are most evident on the eastern side of the island (Hall 1980; McDougall et al. 2001). Landforms such as moraines, striations and sculptured bedrock are described by Hall (1977, 1978, 1980), and are part of a sequence resulting from periods of major ice advance within the Late Pleistocene (Hall 1980) (Fig 4.3). While some debate has existed over the interpretation of sediments as being glacial in origin on Marion Island (Kent \& Gribnitz 1983; Gribnitz et al. 1986), Hall's (1981a) interpretation is now generally accepted as being correct (McDougall et al. 2001).

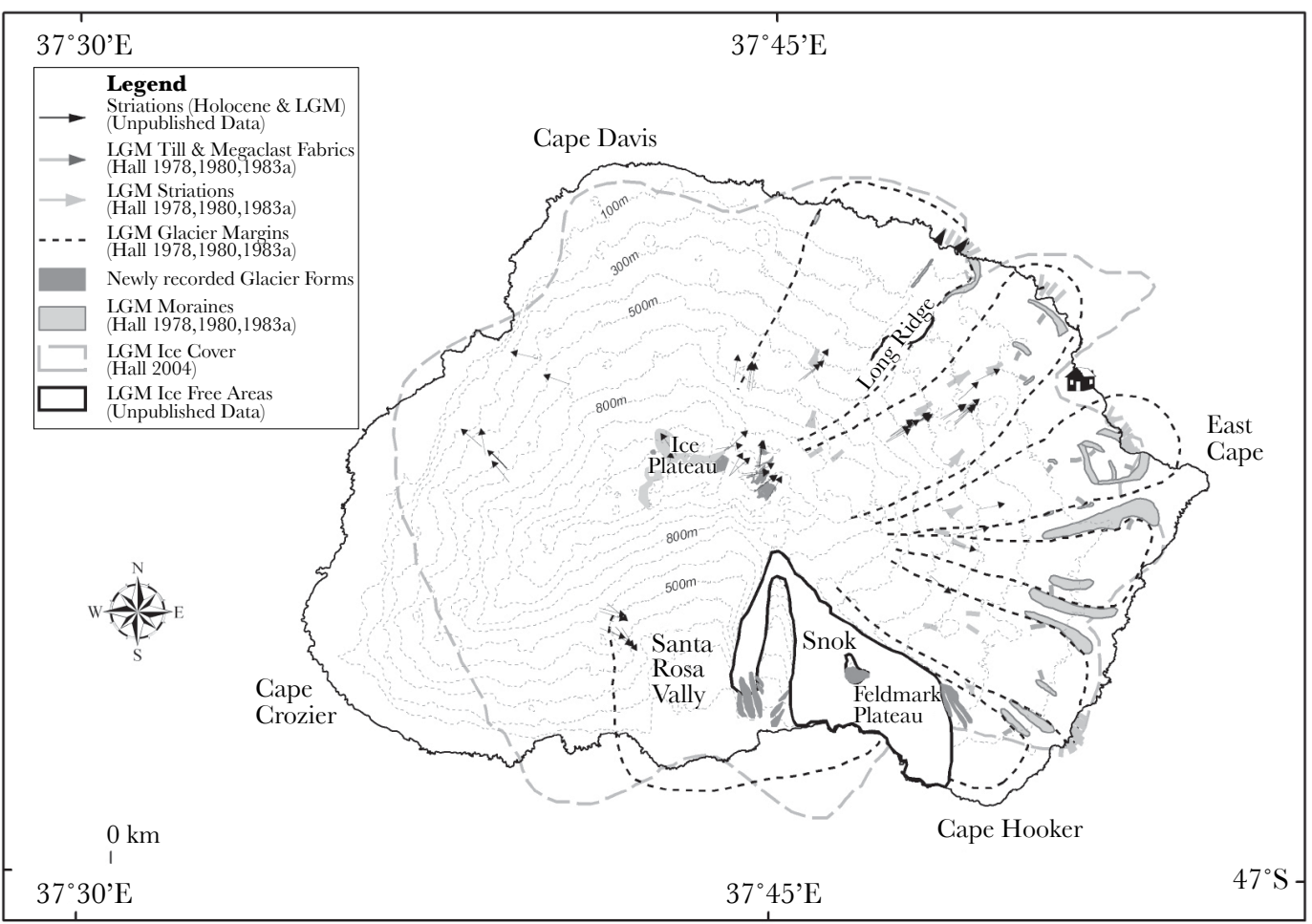

Figure 4.3 Glacial margins, striae, and moraines as identified by Hall (1977, 1978, 1980, 1983a, 2004) and a cirque near Snok. 
The mean annual air temperatures on Marion Island for the Last Glacial Maximum were constructed by estimating the altitudinal range of the palaeo-snowlines from their relationship with the position and altitude of the lateral moraines (Hall 1978, 1980). It was suggested that the mean annual air temperatures on Marion Island fell by $2-4^{\circ} \mathrm{C}$ and that the glaciation of the island resulted from an increase in the amount of precipitation falling as snow (Hall 1982). The location and direction of several former glaciers on the eastern side of Marion Island were proposed from striations on grey lava and from fabric analyses, while the boundaries of the glaciers are indicated by moraines (Hall 1978, 1980) (Fig. 4.3). It is suggested that almost the entire Marion Island was covered by ice during the Last Glacial Maximum (Hall 2004) (Fig 4.3). However, the extent of the glaciation off-shore is unclear.

Rapid deglaciation of Marion Island at the end of the Last Glacial Maximum was proposed as the trigger for the latest volcanic events and movement along scarps, particularly Long Ridge and the Santa Rosa Valley (Hall 1978, 1982, 2004). McDougall et al. (2001), however, disputed the vertical displacement along fault scarps resulting from deglaciation, and as argued below, there is evidence, particularly on Long Ridge, that faulting has not taken place.

Recent research (e.g. Nel 2001; Nel et al. 2003, unpublished data) largely confirmed the spatial extent of palaeo-glaciers suggested by Hall (1978) in the eastern sector (south of Long Ridge to the northern extent of the Feldmark Plateau). Glacial moraines, glacially polished and striated bedrock surfaces identified by Hall (1978, 1980, 1983a, 1990a), have been verified, while previously unrecorded glacial evidence has been documented, particularly in the interior of Marion Island (Hedding 2006).

Apart from the link between rapid deglaciation and massive faulting, the spatial extent of glaciers, particularly on Long Ridge and the Feldmark Plateau, contradict Hall's (1978, 1980, 1982) findings. Moraines, clearly from Late Quaternary glacial events, that exist on the edges of Long Ridge are stable and would have been considerably altered if faulting had occurred, show no evidence of alteration. Similarly, landforms on the edges of Skua Ridge and the Feldmark Plateau show no evidence of faulting. Furthermore, the topography of Feldmark Plateau and Long Ridge, and other similar grey lava areas would have channelled ice-flow away from higher relief areas. Current research (unpublished data) identifies four locations where Hall's (1978, 1980, 1982, 2004) findings on the glacial extent during the Last Glacial Maximum can be reviewed.

First, despite the apparent suitable location of the Feldmark Plateau, specific evidence for the glaciation is sparse. Moraines on the lower northern and southern extents are related to glacial activity in the adjacent low-lying areas, while localised niche glacial activity has been proposed for a basin on the slopes of Snok $(550 \mathrm{~m})$, where a well-developed end moraine has been identified (Boelhouwers et al. 2001). The cirque at Snok consists of a basin in grey lava 
on the lee-side of the Feldmark plateau between 550 and $600 \mathrm{~m}$ a.s.l. (Figs 4.3-4.4), while a terminal moraine exists at $750 \mathrm{~m}$ distance from the backwall. A Holocene scoria cone occupies the central floor and post-dates the moraine. A distinct relict protalus rampart in the vicinity of the backwall indicates a subsequent and more restricted phase of snow accumulation.

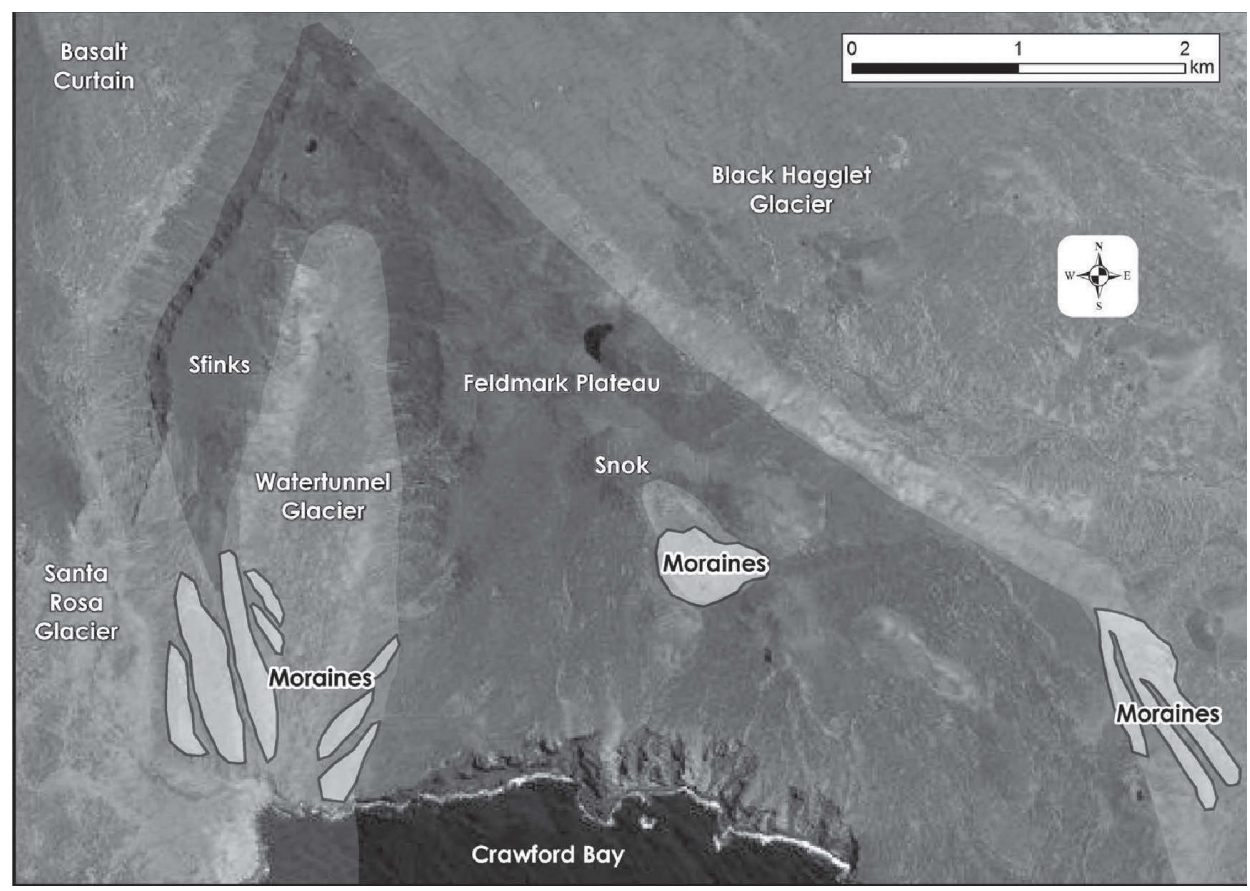

Figure 4.4 Glacial deposits and landforms of the Feldmark and Watertunnel area associated with the last glaciation.

The Feldmark Plateau area is unique with respect to periglacial landforms. Nowhere else on the grey lava areas on Marion Island are there features of comparable size (Holness 2001a; Nel 2001). Holness (2001a) identified extensive blockstreams, stone-banked terraces with risers of up to $3 \mathrm{~m}$ in height and stone-banked lobes up to $4 \mathrm{~m}$ in height. Stone-banked lobes associated with bedrock outcrops have riser heights of approximately $6 \mathrm{~m}$ (Nel 2001). Holness (2001a) argued that the large features on Feldmark Plateau were formed while much of the rest of the island was glaciated. However, it may be, as suggested later in this chapter, that the size of the observed periglacial features is related to location (i.e. on the colder southern slopes of the island) and to the availability of material (Boelhouwers et al. 2001). Nevertheless, it is likely that by channelling ice flow around the high relief of the Feldmark Plateau, the topographic configuration resulted in the area either remaining ice-free through much of the Last Glacial Maximum, or alternatively the area was deglaciated before other areas. 
Second, evidence from Long Ridge suggests that while the area was glaciated during the Last Glacial Maximum, parts remained free of ice, and that the moraines to the north were incorrectly interpreted by Hall (1978, 1983a). The existence of autochtonous blocky deposits (Sumner \& Meiklejohn 2004) associated with a dyke can be used to mitigate against the area being covered by ice (Fig. 4.5). Given the length of time required for development of the blocky deposits (Sumner \& Meiklejohn 2004) and that glaciation would have altered their appearance, it is argued that they have developed under continuous icefree conditions over a long period. However, if the argument presented above is incorrect and the area was glaciated, the inherent stresses associated with deglaciation and dilatation, as well as moisture and temperature regimes, would have been favourable for classic frost to occur, wedging along stressreleased bedrock fractures, thereby resulting in the blockfield development.

Third, reinvestigation of the Watertunnel Valley has led to the identification of small, previously undocumented lateral moraines (Fig. 4.4) that are thought to indicate the retreating frontal zone of a glacier. While the origin of the Watertunnel Valley cannot necessarily be ascribed to glaciation, it clearly has all the characteristics of a glacial valley.

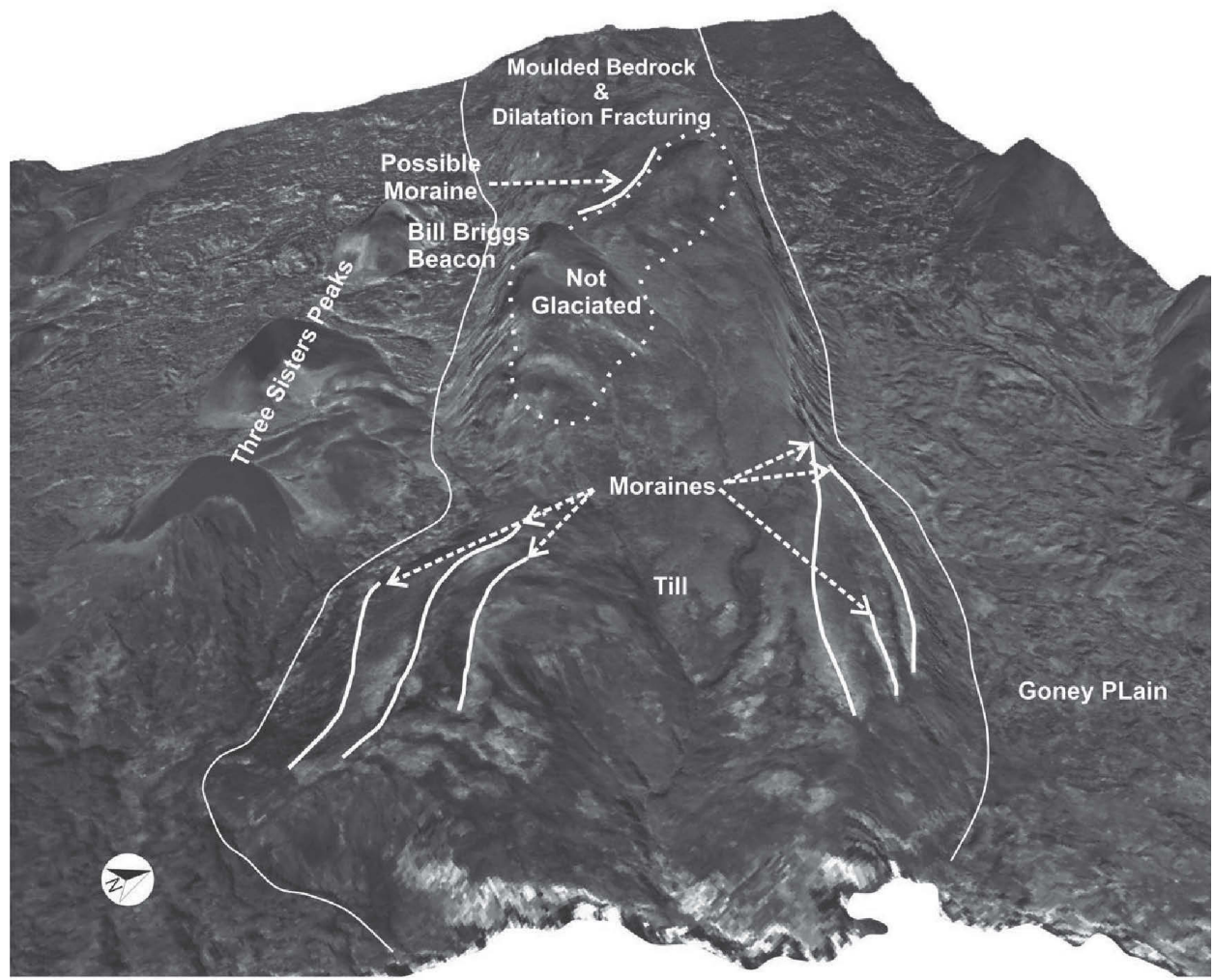

Figure 4.5 Glacial deposits and landforms of the Long Ridge area associated with the last glaciation. 
Fourth, until approximately the year 2000, the interior of Marion Island had a permanent snowline and snow covered evidence for glaciation (Sumner et al. 2004). Climatic amelioration of Marion Island has resulted in the loss of permanent snow cover and the rapid reduction in the size of the Ice Plateau (Sumner et al. 2004) and it is now possible to identify glacial evidence that has previously not been documented. Almost without exception, grey lavas in the high altitude areas of the Island's interior (above $800 \mathrm{~m}$ ) show clear evidence of glaciation in the form of striae, moulded bedrock (including textbook examples of rouche moutonnée forms), moraines, striated clasts and dilatation shattering (Fig. 4.6). While it is assumed that much of the glacial evidence is from the Last Glacial Maximum, Holocene glaciation has occurred from a small icecap, called the "Ice Plateau", and on the slopes of the highest peaks of the island. The extent of Holocene ice cover is currently being investigated, and moraines, striations and three cirques have been identified. However, given that the highest peaks have erupted since the Last Glacial Maximum it is difficult to ascertain the full extent of Holocene glaciation.

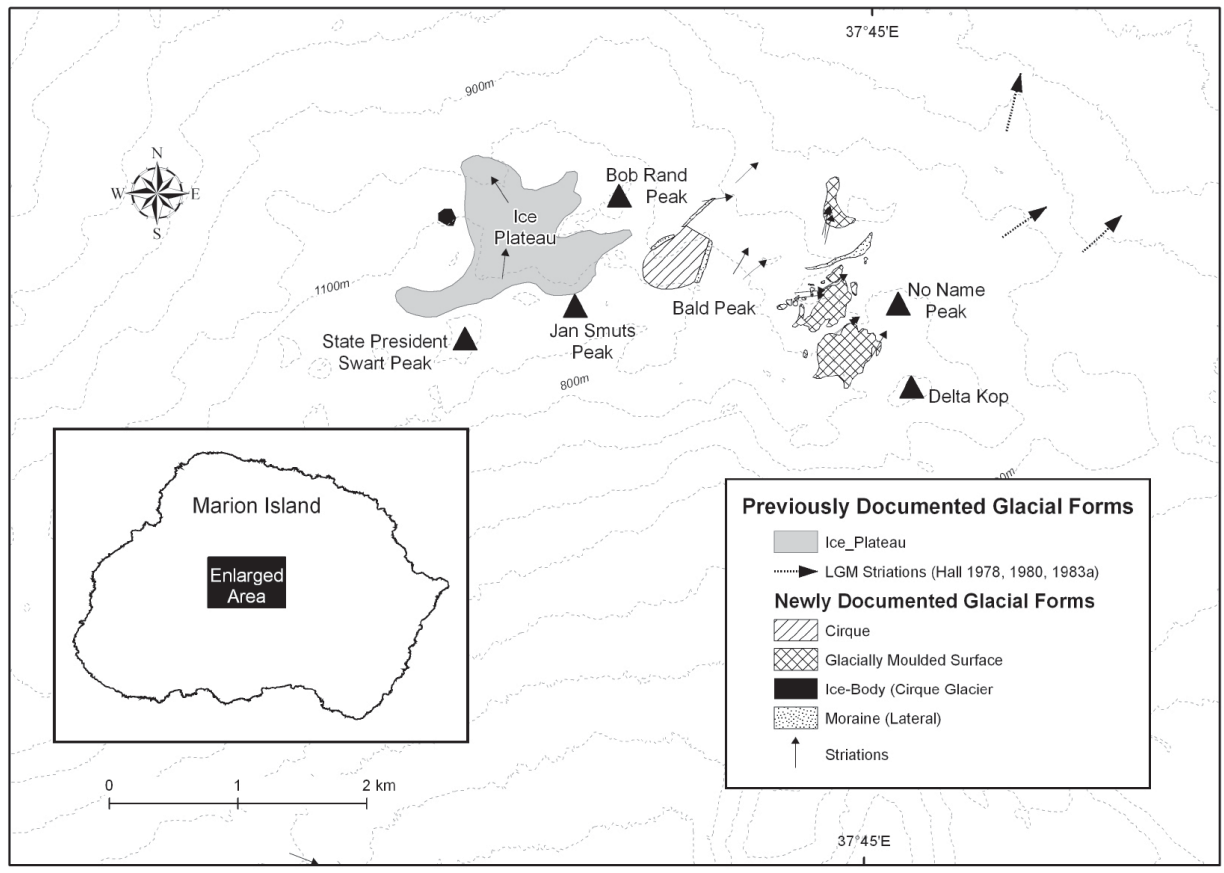

Figure 4.6 Newly recorded glacial evidence from the interior of Marion Island.

The full glacial history on Marion Island remains a conundrum, but with improved spatial resolution of landforms, analyses are beginning to produce a more realistic picture of the island's geomorphology. Further dating by K-Ar and cosmogenic isotopes, and identification and analyses of geomorphic phenomena on Marion Island will not only improve the chronological resolution of landscape development, but will enable more accurate interpretations. 


\subsection{Geomorphology}

The broad landscape features of Marion Island reflect its volcanic origin and have been described in Van Zinderen Bakker et al. (1971). The last glacial cycle has interacted with this structural setting to erode the grey lava surfaces that existed at the time, leading to both glacially polished and striated surfaces, as well as till covers and moraines. Post glacial black lavas vary in age from ten thousand to younger than ten years. The younger lava surfaces have bare, blocky surfaces, while vegetation succession along the coast has led to extensive wetlands and mires. The young terrestrial landscape is highly dynamic as reflected by active coastal cliff erosion, weathering of lava surfaces and basalt outcrops and slope processes on grey lava derived till, debris slopes and scoria cones. Despite the maritime setting, fluvial processes are restricted due to high rates of sub-surface drainage.

Important interactions between animal activity and erosion processes at the coast have been highlighted (Hall \& Williams 1981) and are briefly discussed in this chapter, but have, to date, not received the attention they deserve. An additional consideration for future geomorphic research is that high wind velocities throughout the year potentially have a large impact in areas where vegetation is limited or absent, and which were formerly covered by snow, as is the case for much of the interior of the islands. The result is the exposure of material that is susceptible to transport by wind. Aeolian (wind related) processes are, therefore, likely to play a larger geomorphic role in future and will potentially impact on the colonisation of vegetation.

\subsection{Weathering}

The primary rock structural setting is dominated by the individual lava flow composition, its boundary planes and the columnar cooling joints within the basalt. The blocky surface zone present in the Holocene black lava flows results in a higher porosity and water absorption capacity than grey lava, which in contrast has a higher micro-porosity (Table 4.1). Additional zones of weakness are created by the island scale radial faulting patterns and the post-glacial stress release in the grey lava bedrock. This is visible as surface-parallel fracture patterns with increasing density to the surface that have supplied the platy clasts in the basal till on grey lava surfaces and associated moraines. Stress release upon deglaciation has resulted in blocky disintegration facilitating in situ blockfield development (Sumner \& Meiklejohn 2004) and scree build-up along fault scarps, as described by $\mathrm{Nel}$ et al. (2003).

Sumner (2004) presented a first estimation of current weathering rates by mass loss analysis of small clasts. Black and grey lava samples of $100-380 \mathrm{~g}$ showed mass loss rates of $0.41-0.72 \% \cdot \mathrm{a}^{-1}$ (i.e. per year) and $0.02-0.10 \% \cdot \mathrm{a}^{-1}$, respectively. The grey lava mass loss rates increase consistently with altitude, a trend not observed for the black lava, and are compatible with those reported for quartz-mica schist and marble at Signy Island (Hall 1990b; Hall \& Walton 
1992). Sumner (2004) pointed out that, assuming constant weathering rates, small black lava clasts will completely weather in $c .200$ years, compared to c. 1000 years for grey lava clasts. By contrast, observations along glacially polished grey lava surfaces suggest surface weathering in the order of a few $\mathrm{mm}$ since deglaciation, with striations still visible. Differences in mass to surface area ratio between small clasts and bedrock surfaces may explain some of this discrepancy.

Table 4.1 Rock physical properties of grey and black lava clasts (from Sumner 2004).

\begin{tabular}{|l|l|r|r|r|c|}
\hline \multicolumn{2}{|c|}{ Rock type } & $\begin{array}{c}\text { Porosity } \\
(\%)\end{array}$ & $\begin{array}{c}\text { Mlicro- } \\
\text { porosity } \\
(\%)\end{array}$ & $\begin{array}{c}\text { Water } \\
\text { absorption } \\
(\%)\end{array}$ & $\begin{array}{c}\text { Saturation } \\
\text { coefficient }\end{array}$ \\
\hline Grey lava & mean & 6.04 & 91.84 & 3.63 & 0.61 \\
\hline (n=10) & std. dev. & 0.92 & 3.49 & 0.64 & 0.10 \\
\hline Black lava & mean & 17.86 & 61.67 & 7.65 & 0.47 \\
\hline (n=10) & std. dev. & 6.89 & 8.32 & 0.34 & 0.13 \\
\hline
\end{tabular}

Weathering mechanisms in the sub-Antarctic have been poorly studied. Boelhouwers et al. (2003) presented detailed rock moisture and temperature data for Marion Island and suggest conditions to be favourable for frost action at $1000 \mathrm{~m}$ a.s.l. No studies of chemical weathering have been published, despite its suggested importance in the mass loss study by Sumner (2004) and in soil development and nutrient balance studies.

\subsubsection{Present-day periglacial landforms, processes and environment}

Periglacial geomorphological studies in the sub-Antarctic have mostly focused on landform descriptions with process interpretations based on Northern Hemisphere comparisons (Hall 2002). Recent process studies from Marion Island have provided first insights into the distinct environment-processlandform relationships of the contemporary sub-Antarctic periglacial environment, its permafrost distribution and responses to climate change. As on Macquarie Island, vegetation - geomorphological process relationships are striking in the landscape, but have only received limited attention to date.

\subsubsection{Periglacial landforms}

All till or moraine covered land surfaces and most scoria slopes display evidence of periglacial activity; observed as small forms of patterned ground and solifluction, which occur at all altitudes. Large solifluction terraces and lobes, blockstreams and blockfields and large-scale patterned ground are relict features at all altitudes and are discussed in the context of Holocene climate change. 
The patterned ground of Marion Island has been described in detail (Hall 1979, 1983b; Holness \& Boelhouwers 1998; Holness 2001b; Boelhouwers et al. 2003). The homogeneous material composition of the Marion Island till and scoria slopes results in the strikingly uniform morphology of active patterned ground. This has been used as a basis for dimensional scaling analysis using altitude as a climate proxy from mild coastal conditions to severe-diurnal and seasonal frost environments at the summit (Holness 2003a). Strong positive correlations exist between various circle dimensions and altitude, as well as between the dimensional parameters (Table 4.2). A similar dimensional scaling with altitude for active sorted stripes has been described by Hall (1983c) for Kerguelen and by Boelhouwers et al. (2003) for Marion Island.

A conspicuous characteristic of some sorted stripes on Marion Island is their preferential orientation parallel to the dominant wind direction (Hall 1979). Similar observations are noted for Kerguelen (Hall 1983c) and Macquarie (Löffler 1983). Holness (2001b) noted that, although sorted stripes are oriented down the maximum local slope gradient, sorted stripes occur preferentially on windward slopes and to some extent on low-angled leeward slopes. On nearhorizontal surfaces sorted stripes are aligned with the wind and seldom occur on slopes with cross winds. Holness (2001b) ascribed these spatial patterns to wind-induced surface cooling effects associated with needle ice growth. In addition, surface desiccation would lead to ice crystallisation beneath the dry surface layer, enhancing the geomorphic effectiveness of the frost heave. These observations suggest that wind may play an important role in enhancing diurnal frost effectiveness and its spatial distribution in the sub-Antarctic.

Solifluction landforms have been reported for all sub-Antarctic islands (Hall 2002; Boelhouwers et al. 2003). On Marion Island, stone- and vegetationbanked lobes, sheets and terraces occur at all but the highest altitudes (Hall 1979, 1983b, 1983c). Vegetation-banked solifluction terraces are typically bordered by Azorella selago (Holness \& Boelhouwers 1998; Holness 2003b). At Long Ridge, riser heights of stone- and turf-banked terraces increase with altitude from $c .0 .3 \mathrm{~m}$ to between 0.5 and $1.2 \mathrm{~m}$, over an altitude range from 200 to $550 \mathrm{~m}$ a.s.l. Only the smallest forms are considered active under present-day climate conditions, but larger forms may show secondary, surficial movement on their tread surfaces (Holness \& Boelhouwers 1998).

Stone- and vegetation-banked lobes, sheets and terraces on scoria cones show a distinct internal stratification (Holness 2001b; Boelhouwers et al. 2003). Individual units are comprised of vertically sorted layers that vary in thickness between 5 and $13 \mathrm{~cm}$, but build landforms with riser heights of 0.25 to $1 \mathrm{~m}$ (stone-banked sheets) or 0.5 to $1.5 \mathrm{~m}$ (max. $3.5 \mathrm{~m}$ ) in the case of turf-banked forms (Boelhouwers et al. 2003). These landforms build actively by diurnal frost creep under present-day conditions and closely resemble the features described by Francou (1988, 1989, 1990) and Bertran et al. (1997). These observations illustrate that solifluction landform dimensions may not reflect the severity of the ground frost climate. Rather, here they should be viewed as complex forms 
Table 4.2 Gorrelation coefficients between patterned ground morphometry and environmental parameters. Correlations are significant at $p<0.05$ (based on Holness 2001a, 2003a).

\begin{tabular}{|c|c|c|c|c|c|c|}
\hline \multicolumn{7}{|c|}{ Sorted circles ( $n=121$ sets of 10 circles) } \\
\hline & Altitude & $\begin{array}{l}\text { Slope } \\
\text { angle }\end{array}$ & $\begin{array}{l}\text { Depth } \\
\text { of } \\
\text { sorting }\end{array}$ & $\begin{array}{l}\text { Height } \\
\text { of fine } \\
\text { centre } \\
\text { above } \\
\text { border }\end{array}$ & $\begin{array}{l}\text { Distance } \\
\text { between } \\
\text { fine } \\
\text { centres }\end{array}$ & $\begin{array}{l}\text { Size } \\
\text { of fine } \\
\text { centres }\end{array}$ \\
\hline Slope angle & -0.35 & & & & & \\
\hline $\begin{array}{l}\text { Depth of } \\
\text { sorting }\end{array}$ & 0.95 & -0.36 & & & & \\
\hline $\begin{array}{l}\text { Height of } \\
\text { fine centre } \\
\text { above border }\end{array}$ & 0.93 & -0.40 & 0.89 & & & \\
\hline $\begin{array}{l}\text { Distance } \\
\text { between fine } \\
\text { centres }\end{array}$ & 0.95 & -0.37 & 0.95 & 0.92 & & \\
\hline $\begin{array}{l}\text { Size of fine } \\
\text { centres }\end{array}$ & 0.95 & -0.41 & 0.95 & 0.94 & 0.95 & \\
\hline $\begin{array}{l}\text { Width of } \\
\text { coarse } \\
\text { borders }\end{array}$ & 0.36 & -0.05 & 0.38 & 0.31 & 0.52 & 0.23 \\
\hline
\end{tabular}

\begin{tabular}{|c|c|c|c|c|c|c|}
\hline \multicolumn{7}{|c|}{ Sorted stripes ( $n=150$ sets of 10 pairs of stripes) } \\
\hline & Altitude & $\begin{array}{l}\text { Slope } \\
\text { angle }\end{array}$ & $\begin{array}{l}\text { Depth } \\
\text { of } \\
\text { lateral } \\
\text { sorting }\end{array}$ & $\begin{array}{l}\text { Depth } \\
\text { of } \\
\text { vertical } \\
\text { sorting }\end{array}$ & $\begin{array}{l}\text { Fine } \\
\text { stripe } \\
\text { width } \\
\text { (FSW) }\end{array}$ & $\begin{array}{l}\text { Coarse } \\
\text { stripe } \\
\text { width } \\
\text { (GSW) }\end{array}$ \\
\hline Slope angle & -0.02 & & & & & \\
\hline $\begin{array}{l}\text { Depth of lateral } \\
\text { sorting }\end{array}$ & 0.92 & 0.13 & & & & \\
\hline $\begin{array}{l}\text { Depth of } \\
\text { vertical sorting }\end{array}$ & 0.89 & 0.14 & 0.93 & & & \\
\hline Fine stripe width & 0.93 & 0.05 & 0.95 & 0.89 & & \\
\hline $\begin{array}{l}\text { Coarse stripe } \\
\text { width }\end{array}$ & 0.80 & 0.09 & 0.88 & 0.85 & 0.93 & \\
\hline $\begin{array}{l}\text { Difference } \\
\text { between CSW \& } \\
\text { FSW }\end{array}$ & -0.91 & 0.02 & -0.83 & -0.76 & -0.88 & -0.64 \\
\hline
\end{tabular}


developed under high sediment fluxes during diurnal frost conditions. The spatial patterns of sediment removal, transport and deposition associated with these forms have not been studied. However, there appears to be a dynamic interactive environment between vegetation, slope processes and landforms leading to the growth and senescence of these features.

\subsubsection{Periglacial processes}

Field observations on Marion Island give overwhelming evidence for the occurrence of needle-ice and ice lens formation under diurnal frost cycles. First observed by Van Zinderen Bakker (1973) and Hall (1979), Holness (2001b) described extensive and frequent needle ice growth in all grey lava areas without vegetation or snow cover. Ice lens formation occurs to a depth of $150 \mathrm{~mm}$ at $350 \mathrm{~m}$ a.s.l. and $270 \mathrm{~mm}$ at $700 \mathrm{~m}$ a.s.l.

Sediment heave and downslope movement in the grey lava and scoria areas have been measured by traditional techniques (painted stone lines, wooden dowels, vertical marker columns) from sea level to c. $1000 \mathrm{~m}$ a.s.l. on the east side of the island (Holness 2001b, 2004; Boelhouwers et al. 2003). Movement profiles are typically concave upward in the upper $5-7 \mathrm{~cm}$ and demonstrate the dominance of surficial creep by needle-ice (e.g. Mackay \& Mathews 1974; Pérez 1993; Harris \& Davies 2000; Matsuoka 2005). A solifluction component exists in the profiles above $300 \mathrm{~m}$ a.s.l. as shown by a convex shaped deformation in the lower profile sections. This reaches down to $20 \mathrm{~cm}$ at $1000 \mathrm{~m}$ a.s.l. In some places shearing at $6-8 \mathrm{~cm}$ is observed at the zone that differentiates the faster, surficial, needle-ice dominated creep from the solifluction zone beneath. Rates and depths of wooden dowel heave highlight the effective differential frost heave associated with needle ice and indicate ice lens formation above $300 \mathrm{~m}$ a.s.l. (Holness 2004). Holness (2001a) demonstrated re-growth of sorted stripes on a scoria cone at $550 \mathrm{~m}$ a.s.l. within one winter season.

Sediment movement rates of markers on till and scoria slopes compare well with those of other sub-Antarctic islands, are on par with alpine diurnal frost environments and are among the highest in any periglacial environment (Table 4.3). Fine-textured soils show significantly higher movement rates than coarse materials (Holness 2001a, 2004). Holness (2001a, 2004) used multivariate analysis to identify factors controlling movement rates in both the scoria and till materials. Slope angle, altitude and percentage fines were identified as significant controls $(p=0.05)$ for the scoria and till, explaining $65 \%$ and $49 \%$ of the movement variability, respectively (Holness 2004). Better correlations with these three environmental parameters can be found by separating the sites by surface texture in the till, explaining $72 \%, 62 \%$ and $38 \%$ of the variability in fine, stony and blocky sites respectively. 
Table 4.3 Average sediment movement rates on grey lava, till and scoria slopes (from Holness 2001a).

\begin{tabular}{|c|c|c|c|c|c|c|c|}
\hline & & & Grey lava & nd till slope & & & \\
\hline Altit & & Slope & $\begin{array}{c}\%<63 \mathrm{ym} \\
\text { of the }\end{array}$ & Averag & $\mathrm{mov}$ & $\begin{array}{l}\text { ment } r \\
\text { ear) }\end{array}$ & ites \\
\hline$(\mathrm{m}$ a & S.1.) & angle & fraction & Cambined & Fing & Streng & Rlockv \\
\hline 75 & Avg & 3.9 & 12.6 & 21.8 & 57.6 & 20.4 & 0.9 \\
\hline & S.D. & 3.0 & 3.1 & 13.7 & 22.1 & 13.4 & 1.9 \\
\hline 150 & Avg & 5.4 & 19.2 & 10.7 & 29.0 & 11.7 & 4.2 \\
\hline & S.D. & 2.1 & 8.3 & 4.8 & 5.5 & 6.0 & 7.4 \\
\hline 200 & Avg & 3.6 & 9.1 & 42.7 & 84.0 & 27.8 & 5.9 \\
\hline & S.D. & 3.0 & 2.5 & 24.5 & 32.9 & 13.3 & 9.2 \\
\hline 300 & Avg & 6.8 & 15.0 & 50.1 & 157.0 & 53.4 & 0.0 \\
\hline & S.D. & 3.1 & 5.8 & 46.4 & 58.0 & 25.3 & 0.1 \\
\hline 550 & Avg & 8.1 & 11.3 & 90.5 & 302.7 & 95.1 & 32.3 \\
\hline & S.D. & 5.1 & 4.0 & 62.0 & 215.3 & 55.9 & 39.9 \\
\hline 750 & Avg & 13.4 & 25.4 & 276.8 & 464.1 & 170.4 & 45.8 \\
\hline & S.D. & 8.6 & 7.9 & 319.2 & 494.6 & 168.2 & 59.7 \\
\hline 1000 & Avg & 8.0 & 3.6 & 109.7 & 257.1 & 115.7 & 40.1 \\
\hline & S.D. & 4.3 & 1.7 & 49.5 & 28.0 & 49.3 & 27.0 \\
\hline All sites & Avg & 7.1 & 13.3 & 81.5 & 180.7 & 65.5 & 17.4 \\
\hline & S.D. & 5.2 & 7.9 & 135.8 & 239.4 & 80.2 & 33.2 \\
\hline
\end{tabular}

\begin{tabular}{|c|c|c|c|c|c|c|c|}
\hline \multicolumn{8}{|c|}{ Scoria slopes } \\
\hline \multirow{2}{*}{\multicolumn{2}{|c|}{$\begin{array}{l}\text { Altitude } \\
\text { (m a.s.1.) }\end{array}$}} & \multirow{3}{*}{$\begin{array}{l}\text { Slope } \\
\text { angle } \\
\qquad 8\end{array}$} & \multirow{3}{*}{$\begin{array}{l}\%<63 \mathrm{ym} \\
\text { of the } \\
\text { fraction } \\
<2 \mathrm{~mm} \\
17\end{array}$} & \multicolumn{4}{|c|}{$\begin{array}{l}\text { Average movement rates } \\
\qquad(\mathrm{mm} / \text { year })\end{array}$} \\
\hline & & & & \multirow{2}{*}{$\begin{array}{c}\text { Combined } \\
36\end{array}$} & \multirow{2}{*}{ Fine } & \multirow{2}{*}{$\begin{array}{c}\text { Stony } \\
36\end{array}$} & \multirow{2}{*}{ Blocky } \\
\hline 150 & Avg & & & & & & \\
\hline & S.D. & 3 & 5 & 9 & & 9 & \\
\hline \multirow[t]{2}{*}{200} & Avg & 17 & 12 & 143 & 406 & 142 & 26 \\
\hline & S.D. & 7 & 6 & 156 & 262 & 134 & 23 \\
\hline \multirow[t]{2}{*}{550} & Avg & 16 & 17 & 600 & 757 & 384 & \\
\hline & S.D. & 6 & 11 & 406 & 392 & 286 & \\
\hline \multirow[t]{2}{*}{750} & Avg & 8 & 4 & 124 & & 124 & \\
\hline & S.D. & 5 & 1 & 96 & & 96 & \\
\hline \multirow[t]{2}{*}{750} & Avg & 14 & 4 & 80 & 125 & 49 & \\
\hline & S.D. & 1 & 0 & 61 & 42 & 22 & \\
\hline \multirow[t]{2}{*}{ All sites } & Avg & 15 & 12 & 216 & 532 & 161 & 26 \\
\hline & S.D. & 7 & 8 & 281 & 382 & 179 & 23 \\
\hline
\end{tabular}




\subsubsection{The periglacial environment}

At the island scale, material distribution poses the most obvious control on the spatial distribution of soil frost processes and landforms. Frost susceptibility has been defined by Holness (2001a), using Meentemeyer \& Zippin's (1981) threshold value of $7.9 \%$ as the minimum percentages of fines (fraction $<63 \mu \mathrm{m}$ ) for saturated soils to develop segregation ice. Precipitation recorded on average 26 days per month at the meteorological station suggests that high soil moisture conditions prevail throughout the year on the island. At lower altitudes this is further enhanced by rapid snowmelt during the winter months. Based on monthly gravimetric sampling at 13 sites, Holness (2001a) concluded that in grey lava areas moisture and soil texture provide no constraint for segregation ice growth except during occasional dry spells. Scoria materials show a stronger spatial heterogeneity in fines and moisture content, leading to a higher potential spatial variability in soil frost process activity and associated landforms. Finally, all black lava areas were found to be non-frost susceptible and contain insufficient moisture for needle ice growth.

The maritime, mid-latitudinal setting of Marion Island results in low annual and diurnal temperature ranges. Mean annual ground surface temperatures range from +5.5 to $+1.4^{\circ} \mathrm{C}$, from sea level to $1000 \mathrm{~m}$ a.s.l., respectively (Boelhouwers et al. 2003). The near-surface air temperature lapse rate is $0.5^{\circ} \mathrm{C} / 100 \mathrm{~m}$, which is marginally higher than the $0.45^{\circ} \mathrm{C} / 100 \mathrm{~m}$ summer, and $0.4^{\circ} \mathrm{C} / 100 \mathrm{~m}$ winter lapse rates measured in the free atmosphere (Schulze 1971). The island's thermal regime results in a soil frost climate dominated by diurnal frost cycles. Table 4.4 describes the increased frequency of soil frost cycles, freeze days and frost depth penetration with altitude as measured at four ground temperature logging sites. At $200 \mathrm{~m}$ a.s.l. soil frost is restricted to the May-September period, but occurs throughout the year at higher altitudes.

Despite the dominant diurnal frost environment, Boelhouwers (2003) reported the existence of permafrost at altitudes above $1000 \mathrm{~m}$ a.s.l. Permafrost conditions occur in valley bottoms and on insolation-protected south and east facing ice-cemented slopes of scoria cones, which maintain slope angles of $46^{\circ}$, well in excess of the angle of repose of $36^{\circ}$ at low altitudes. In addition, cryotic ground conditions are associated with snow and ice bodies in the summit region. Most of the existing permafrost is rapidly degrading, or has already disappeared, under current climate warming.

Slope aspect may also influence the local radiation budget and resulting thermal regime. Recent measurements of soil surface temperature around a coastal volcanic cone indicate that the role of aspect is strongly dependent on cloud cover and air circulation conditions (J. Boelhouwers, unpublished data). Overcast conditions associated with westerly circulation result in minimal ground temperature contrasts with slope aspect. By contrast, clear sky conditions under southerly air circulation result in strongly contrasting daytime differences in magnitude and timing of temperature change. Differences 
by aspect in nocturnal radiative heat loss are also enhanced under clear sky conditions with shaded slopes more readily reaching ground frost conditions. Thus, while the generally high cloud cover conditions minimize the role of slope aspect on ground frost frequency, climate change impact studies must consider the impact of change in cloud cover. Smith (2002) described a $c .200$ hour, or c. $16 \%$, increase in sunshine hours over the period 1951 to 1999 . This trend is likely to enhance thermal contrasts by slope aspect and may partially offset warming trends through enhanced nocturnal cooling and, thus, maintain a high soil frost potential. This may in turn enhance spatial variability in soil movement rates by frost creep and solifluction.

Table 4.4 Soil frost frequency, intensity, duration for different altitudes (from Boelhouwers et al. 2003).

\begin{tabular}{|c|c|c|c|c|c|c|c|}
\hline & $+10 \mathrm{~cm}$ & $-1 \mathrm{~cm}$ & $-5 \mathrm{~cm}$ & $-10 \mathrm{~cm}$ & $-20 \mathrm{~cm}$ & $-40 \mathrm{~cm}$ & $-80 \mathrm{~cm}$ \\
\hline \multicolumn{8}{|c|}{ Long Ridge North (200 m a.s.1.) June 1998 - April 2000} \\
\hline Mean Annual Temp. $\left({ }^{\circ} \mathrm{C}\right)$ & 4.8 & 5.5 & 5.5 & 5.5 & 5.7 & 5.7 & \\
\hline Freezing index & -9.5 & -3.5 & 0 & 0 & 0 & 0 & \\
\hline Freeze/thaw days $(\mathrm{n} / \mathrm{a})$ & 87 & 62.5 & 1 & 0 & 0 & 0 & \\
\hline Freeze days $(\mathrm{n} / \mathrm{a})$ & 3.5 & 4 & 0 & 0 & 0 & 0 & \\
\hline $\begin{array}{l}\text { Days (n/a) with temps: } \\
\qquad 0^{\circ} \mathrm{C} \text { to }>-2^{\circ} \mathrm{C} \\
-2^{\circ} \mathrm{C} \text { to }>-4^{\circ} \mathrm{C} \\
\leq-4^{\circ} \mathrm{C}\end{array}$ & $\begin{array}{l}71.5 \\
22.5 \\
3\end{array}$ & $\begin{array}{l}61.5 \\
10.5 \\
0\end{array}$ & $\begin{array}{l}1 \\
0 \\
0\end{array}$ & $\begin{array}{l}0 \\
0 \\
0\end{array}$ & $\begin{array}{l}0 \\
0 \\
0\end{array}$ & $\begin{array}{l}0 \\
0 \\
0\end{array}$ & \\
\hline
\end{tabular}

Katedraallurans Nek (750 m a.s.1.) May 1997 - October 1998

\begin{tabular}{|l|c|c|c|c|c|c|c|||}
\hline Mean Annual Temp. $\left({ }^{\circ} \mathrm{C}\right)$ & 1.5 & 2.5 & 2.2 & 2.3 & 2.3 & 1.9 & \\
\hline Freezing index & -194.6 & -99.6 & -73.3 & -31.1 & -25.2 & -36.9 & \\
\hline Freeze/thaw days (n/a) & 189.5 & 180.5 & 126 & 29 & 19.5 & 14.5 & \\
\hline Freeze days (n/a) & 98.5 & 114 & 126 & 106.5 & 97 & 103 & \\
\hline $\begin{array}{l}\text { Days (n/a) with temps: } \\
\quad\end{array}$ & 131.5 & 204.5 & 245.5 & 135.5 & 116.5 & 117.5 & \\
$0^{\circ} \mathrm{C}$ to $>-2^{\circ} \mathrm{C}$ & 101 & 75.5 & 6.5 & 0 & 0 & 0 & \\
$-2^{\circ} \mathrm{C}$ to $>-4^{\circ} \mathrm{C}$ & 55.5 & 14.5 & 0 & 0 & 0 & 0 & \\
$\leq-4^{\circ} \mathrm{C}$ & & & & & & & \\
\hline
\end{tabular}

Delta extension (1000 m a.s.1.) April 1999 - April 2000

\begin{tabular}{|l|c|c|c|c|c|c|c|}
\hline Mean Annual Temp. $\left({ }^{\circ} \mathrm{C}\right)$ & 0.8 & 1.4 & 1.8 & 1.2 & 1.7 & 2.0 & 2.0 \\
\hline Freezing index & -372.9 & -215.4 & -86.0 & -96.4 & -7.6 & 0 & 0 \\
\hline Freeze/thaw days (n/a) & 221 & 212 & 121 & 68 & 27 & 0 & 0 \\
\hline $\begin{array}{l}\text { Freeze days (n/a) } \\
\text { Days (n/a) with temps: }\end{array}$ & 59 & 43 & 42 & 126 & 110 & 0 & 0 \\
$\quad 0^{\circ} \mathrm{C}$ to $>-2^{\circ} \mathrm{C}$ & 80 & 115 & 116 & 181 & 137 & 0 & 0 \\
$\quad-2^{\circ} \mathrm{C}$ to $>-4^{\circ} \mathrm{C}$ & 92 & 75 & 40 & 13 & 0 & 0 & 0 \\
$\leq-4^{\circ} \mathrm{C}$ & 108 & 65 & 7 & 0 & 0 & 0 & 0 \\
\hline
\end{tabular}


The role of snow on the ground thermal regime is generally considered to be one of insulation that limits ground frost cycles beneath the snow cover (e.g. Chambers 1966; Thorn 1979; Matsuoka 1996). Temperature profiles at Katedraalkrans describe near-isothermal conditions beneath snow, the lack of frost cycles and the reduction in soil frost intensity, at the soil surface. However, in contrast to regions with high seasonal and diurnal temperature ranges (Benedict 1976), snow cover has a distinct cooling effect on the underlying soils. The snow cooling effect extends the soil freeze from $10 \mathrm{~cm}$ to $40 \mathrm{~cm}$ depth and maintains a low intensity freeze until snow melt (Holness 2001a, 2003b). This explains the higher number of freeze days at the snow-rich site of Katedraalkrans Nek, compared to the snow-free, higher elevation, site of Delta extension (Table 4.4). Similar results from South Georgia (Smith 1960; Heilbronn \& Walton 1984) suggest that this is a regional phenomenon. On Marion Island, above $750 \mathrm{~m}$ a.s.l. snow cover is present for much of the winter period, but is spatially discontinuous due to rapid wind re-distribution. This results in spatially heterogeneous ground frost conditions, favouring soil frost processes at wind exposed sites. Snow accumulation at preferential sites above $1000 \mathrm{~m}$ a.s.l. survives over the summer period, thus further limiting periglacial process activity. The sites create local cryotic ground conditions, especially where additional insulation results from sediment deposition on snow bodies by wind or mass movements.

The new insights from the soil frost process studies highlight that although fundamental mechanisms are the same, the uniform material and moisture conditions much simplify the spatial patterns of movement dynamics on the island. The distinct combination of environmental conditions results in a periglacial process regime that is distinct from other periglacial landscapes and highly active. Slope angle, the altitudinal gradient of the soil frost regime (frost cycle frequency and depth), percentage fines, slope aspect, wind and vegetation interactions emerge as important environmental variables in understanding the spatial pattern and intensity of sediment movement rates. Some of these driving factors are sensitive to ongoing climate change. The emerging empirical database provides a basis for the spatial modelling of the landscape-scale terrestrial geomorphic dynamics of Marion Island to improve quantitative understanding of its responses to climate change and ecosystem interactions.

\subsubsection{Other slope processes}

In addition to the slow mass wasting processes induced by soil frost conditions, a range of rapid mass wasting landforms exists on the island. At present no full inventory of rapid mass wasting forms has been undertaken, but is most likely to have its largest concentration along the escarpment zone that separates the west island coastal platform from the interior slope. To date, observations have mostly focused on the eastern sector of the island as summarized by Nel et al. (2003). The authors described the occurrence of translational and rotational 
slides and debris flows on peat slopes at altitudes below $400 \mathrm{~m}$ a.s.l. and at slope angles from $17^{\circ}$ to $55^{\circ}$. Translational slides are noted to be shallow $(<1 \mathrm{~m})$ with the plane of failure either within the peat or at the bedrock contact. Rotational slides in peat are noted for drier parts of the island. Debris flows in the peat are channel-confined and appear triggered by disintegration of material released by peat slides. These observations on the peat slopes of Marion Island closely resemble those described for Macquarie Island (Campbell 1981; Selkirk 1998; Selkirk-Bell 2000). Similar to Macquarie Island, gradual peat accumulation is thought to increase shear stress over time, with failure being triggered by heavy rainfall events (Selkirk-Bell 2000; Nel et al. 2003).

Screes flank most scarps that border grey lava areas. Their surface material is largely stable as indicated by extensive lichen cover, but some rockfall activity is still ongoing (Nel et al. 2003). Small debris flows are described for a scoria cone by Boelhouwers et al. (2000). These are associated with low permeability surfaces where frost-heaved surface material becomes saturated, triggering the debris flow. Landforms are rapidly obliterated during subsequent frost heave events. Holness (2004) considered these flow events to be highly restricted spatially due to the general high permeability of the scoria slope surfaces.

No sediment budgets studies have been undertaken on Marion Island and especially the understanding of non-periglacial slope dynamics is still far from complete. There is no consensus as to the dominance of periglacial slope processes in the sub-Antarctic. However, on Marion Island slope materials have now been demonstrated to be highly mobile by diurnal frost creep and solifluction and to be more important than surface runoff. The volcanic materials with their high permeability are likely to reduce the effects of slope wash, which have been argued to be important on Macquarie Island (Taylor 1955a, 1955b; Selkirk 1998; Selkirk-Bell 2000). Rapid mass wasting is likely to be important both in terms of sediment fluxes and as a landscape disturbance factor in specific zones. To date no research has focused on these dynamics in any depth.

\subsubsection{Zoogeomorphology}

Although it is clear that periglacial (and previously glacial processes) are the major agents of geomorphic change in the interior and higher altitude areas of Marion Island, in the coastal areas the erosion, transport and deposition of sediment by wild animals may play a dominant role in shaping sections of the landscape.

Although a range of bird and marine mammal species is present on Marion Island, only nine species appear to play a significant role in shaping the landscape (Table 4.5). Each of these species has specific geomorphic impacts, and these impacts vary spatially according to their specific habitat usage pattern and behaviour. Further, through impacting populations of these species, humans have altered the geomorphic effectiveness of these agents and have altered the landscape. 
Table 4.5 Key zoogeomorphic agents on Marion Island.

\begin{tabular}{|c|c|c|c|c|}
\hline & Geomorphic action & Spatial extent & Populations & $\begin{array}{c}\text { Anthropogenic } \\
\text { influences }\end{array}$ \\
\hline \multicolumn{5}{|c|}{ Surface nesting, flightless colonial seabirds } \\
\hline $\begin{array}{l}\text { King } \\
\text { Penguins }\end{array}$ & $\begin{array}{l}\text { Complete removal } \\
\text { of peat and other } \\
\text { unconsolidated material } \\
\text { within large breeding } \\
\text { colony boundaries. } \\
\text { Extensive breeding } \\
\text { areas of up to } 50 \text { ha at } \\
\text { Sea Elephant Bay to } \\
\text { Log Beach. }\end{array}$ & $\begin{array}{l}\text { High density } \\
\text { colonies on flat } \\
\text { or gently sloping } \\
\text { terrain adjacent to } \\
\text { the coast. Impacts } \\
\text { concentrated in a } \\
\text { few large colonies. }\end{array}$ & $\begin{array}{l}165000 \text { to } \\
380000 \\
\text { breeding } \\
\text { pairs (based } \\
\text { on various } \\
\text { estimates and } \\
\text { dates) }\end{array}$ & \\
\hline $\begin{array}{l}\text { Macaroni } \\
\text { Penguins }\end{array}$ & $\begin{array}{l}\text { Complete removal } \\
\text { of peat and other } \\
\text { unconsolidated } \\
\text { material within colony } \\
\text { boundaries. Erosion of } \\
\text { gullies and grooving of } \\
\text { bedrock along paths } \\
\text { to interior colonies. } \\
\text { Observations of peat } \\
\text { erosion to depth } 1.4 \mathrm{~m} \\
\text { up to } 5 \mathrm{~m} \text { over an area } \\
\text { of } 10 \text { ha at Kildalkey } \\
\text { Bay suggest a total of } \\
285000 \mathrm{~m}^{3} \text { removed. }\end{array}$ & $\begin{array}{l}\text { High density } \\
\text { colonies on flat } \\
\text { or gently sloping } \\
\text { terrain adjacent } \\
\text { to the coast, with } \\
\text { some colonies } \\
\text { on steeper rocky } \\
\text { slopes or further } \\
\text { inland where } \\
\text { coastal sites not } \\
\text { available. Impacts } \\
\text { concentrated in a } \\
\text { few large colonies } \\
\text { in peat areas. }\end{array}$ & $\begin{array}{l}356000 \text { to } \\
434000 \\
\text { breeding pairs }\end{array}$ & \\
\hline $\begin{array}{l}\text { Rockhopper } \\
\text { Penguins }\end{array}$ & $\begin{array}{l}\text { Impacts limited by } \\
\text { habitat preferences, } \\
\text { but some limited } \\
\text { striation of rock } \\
\text { and removal of peat } \\
\text { and unconsolidated } \\
\text { sediment where colonies } \\
\text { extend beyond un- } \\
\text { vegetated lava areas. }\end{array}$ & $\begin{array}{l}\text { Rugged black } \\
\text { lava areas along } \\
\text { the coast. Less } \\
\text { concentrated } \\
\text { colonies than the } \\
\text { other two species. }\end{array}$ & $\begin{array}{l}67000 \text { to } \\
173000 \\
\text { breeding pairs }\end{array}$ & \\
\hline
\end{tabular}


Table 4.5 Continued

\begin{tabular}{|c|c|c|c|c|}
\hline & Geomorphic action & Spatial extent & Populations & $\begin{array}{c}\text { Anthropogenic } \\
\text { influences }\end{array}$ \\
\hline \multicolumn{5}{|c|}{ Burrowing seabirds } \\
\hline Salvins Prions & $\begin{array}{l}\text { Excavation of burrows } \\
\text { at average densities of } \\
\text { up to 88- } 115 \text { burrows/ } \\
\text { ha in favoured habitats. } \\
\text { Burrow volumes } \\
\text { average } 0.05 \mathrm{~m}^{3} \\
\text { implying } 5.8 \mathrm{~m}^{3} / \text { ha } \\
\text { excavated in favoured } \\
\text { habitats. Total moved } \\
\text { for Marion Island } \\
4610 \mathrm{~m}^{3} \text { to } 46104 \mathrm{~m}^{3} \text {. }\end{array}$ & $\begin{array}{l}\text { Vegetated } \\
\text { hummocky } \\
\text { black lava } \\
\text { areas especially } \\
\text { favouring closed } \\
\text { fernbrake and } \\
\text { Acaena herbfield, } \\
\text { also using Poa } \\
\text { tussock grassland }\end{array}$ & $\begin{array}{l}100 \text { s of } 1000 \\
\text { breeding } \\
\text { pairs. }\end{array}$ & $\begin{array}{l}\text { Feral cats } \\
\text { were rapidly } \\
\text { exterminating } \\
\text { burrowing petrel } \\
\text { populations } \\
(455000 / \mathrm{a}) \text { in } \\
\text { the } 1970 \text { s and } \\
1980 \text { s. There } \\
\text { has been a } \\
\text { rapid recovery } \\
\text { of populations } \\
\text { since cats were } \\
\text { eliminated. }\end{array}$ \\
\hline Blue Petrels & $\begin{array}{l}\text { Excavation of burrows } \\
\text { at average densities } \\
\text { of up to } 105-189 \\
\text { burrows } / \text { hectare in } \\
\text { favoured habitats. } \\
\text { Burrow volumes } \\
\text { average } 0.05 \mathrm{~m}^{3} \\
\text { imply approximately } \\
9.5 \mathrm{~m}^{3} / \text { ha excavated } \\
\text { in favoured habitats. } \\
\text { Produces characteristic } \\
\text { hummocky terrain in } \\
\text { dense colonies. Total } \\
\text { moved for Marion } \\
\text { Island } 461 \mathrm{~m}^{3} \text { to } \\
4610 \mathrm{~m}^{3} \text {. }\end{array}$ & $\begin{array}{l}\text { Vegetated flatter } \\
\text { areas especially } \\
\text { favouring Cotula } \\
\text { herbfield, also } \\
\text { using Poa tussock } \\
\text { grassland }\end{array}$ & $\begin{array}{l}10 \text { s of } 1000 \\
\text { breeding } \\
\text { pairs. }\end{array}$ & \\
\hline $\begin{array}{l}\text { Greatwinged } \\
\text { Petrels }\end{array}$ & $\begin{array}{l}\text { Excavation of burrows } \\
\text { at average densities of } \\
11-46 \text { burrows/hectare } \\
\text { in favoured habitats. } \\
\text { Burrow volumes } \\
\text { average } 0.12 \mathrm{~m}^{3} \\
\text { imply approximately } \\
5.5 \mathrm{~m}^{3} / \text { ha excavated } \\
\text { in favoured habitats. } \\
\text { Total moved for Marion } \\
\text { Island } 1222 \mathrm{~m}^{3} \text { to } \\
12220 \mathrm{~m}^{3} .\end{array}$ & $\begin{array}{l}\text { Vegetated } \\
\text { hummocky } \\
\text { areas especially } \\
\text { favouring Poa } \\
\text { tussock grassland, } \\
\text { as well as closed } \\
\text { fernbrake and to a } \\
\text { lesser extent Cotula } \\
\text { herbfield. }\end{array}$ & $\begin{array}{l}10 \text { s of } 1000 \\
\text { breeding } \\
\text { pairs. }\end{array}$ & \\
\hline
\end{tabular}


Table 4.5 Continued

\begin{tabular}{|c|c|c|c|c|}
\hline & Geomorphic action & Spatial extent & Populations & $\begin{array}{l}\text { Anthropogenic } \\
\text { influences }\end{array}$ \\
\hline \multicolumn{5}{|c|}{ Burrowing seabirds } \\
\hline $\begin{array}{l}\text { Whitechinned } \\
\text { Petrels }\end{array}$ & $\begin{array}{l}\text { Excavation of burrows } \\
\text { at average densities of } \\
\text { up to } 15-31 \text { burrows/ } \\
\text { hectare in favoured } \\
\text { habitats. Burrow } \\
\text { volumes average } 0.4 \mathrm{~m}^{3} \\
\text { imply approximately } \\
12.4 \mathrm{~m}^{3} / \text { ha excavated } \\
\text { in favoured habitats. } \\
\text { Nest structure includes } \\
\text { a characteristic flooded } \\
\text { entrance. Nests often } \\
\text { associated with local } \\
\text { slope collapse. Total } \\
\text { moved for Marion } \\
\text { Island } 3956 \mathrm{~m}^{3} \text { to } \\
39563 \mathrm{~m}^{3} \text {. }\end{array}$ & $\begin{array}{l}\text { Vegetated } \\
\text { hummocky } \\
\text { areas especially } \\
\text { favouring } P o a \\
\text { tussock grassland } \\
\text { and Acaena } \\
\text { herbfield. }\end{array}$ & $\begin{array}{l}\text { 10s of } 1000 \\
\text { breeding pairs }\end{array}$ & \\
\hline \multicolumn{5}{|l|}{ Seals } \\
\hline $\begin{array}{l}\text { Sub-Antarctic } \\
\text { Fur Seals }\end{array}$ & $\begin{array}{l}\text { Localized trampling } \\
\text { and disruption of } \\
\text { vegetation occurs } \\
\text { where breeding } \\
\text { colonies extend onto } \\
\text { vegetated areas. }\end{array}$ & $\begin{array}{l}\text { Impacted areas } \\
\text { include Poa tussock } \\
\text { grassland and } \\
\text { Cotula herbfield } \\
\text { adjacent to } \\
\text { landing beaches. }\end{array}$ & 48658 & $\begin{array}{l}\text { Exploitation } \\
\text { started in 1803; } \\
\text { within } 7 \text { years } \\
\text { fur seals were } \\
\text { economically } \\
\text { extinct. } \\
\text { Populations } \\
\text { (along with the } \\
\text { less common } \\
\text { Antarctic Fur } \\
\text { Seal) now rapidly } \\
\text { expanding. }\end{array}$ \\
\hline $\begin{array}{l}\text { Elephant } \\
\text { Seals }\end{array}$ & $\begin{array}{l}\text { The great bulk of these } \\
\text { animals flattens and } \\
\text { compacts vegetation } \\
\text { and peat bogs creating } \\
\text { local hollows that } \\
\text { coalesce and deepen } \\
\text { to form composite } \\
\text { wallows. Local drainage } \\
\text { is disrupted, and a } \\
\text { distinctive topography } \\
\text { of vegetated ridges } \\
\text { with intervening } \\
\text { wallows results. }\end{array}$ & $\begin{array}{l}\text { Moulting areas } \\
\text { usually in Poa } \\
\text { tussock grassland } \\
\text { and Cotula } \\
\text { herbfield adjacent } \\
\text { to sandy or stony } \\
\text { beaches where } \\
\text { landing is possible. }\end{array}$ & 2009 & $\begin{array}{l}\text { Mostly exploited } \\
\text { from } 1810 \text { to } \\
1860 \text { by which } \\
\text { time elephant } \\
\text { seals were } \\
\text { economically } \\
\text { extinct. Initial } \\
\text { population } \\
\text { recovery trends } \\
\text { appear to be } \\
\text { reversing. }\end{array}$ \\
\hline
\end{tabular}

Burrow volumes and impact observations from Holness unpublished data, burrow densities and habitat preferences from Schramm (1986), petrel populations from Cooper \& Brown (1990), penguin populations from Crawford et al. (2003), seal populations and exploitation from Hänel \& Chown (1998). 
From a geomorphological point of view the nine keystone species can be divided into three broad groups, namely surface nesting flightless colonial seabirds, burrowing seabirds, and seals (Table 4.5). Surface nesting colonial seabirds result in significant, but localized, erosion. Macaroni and King penguins have the greatest geomorphic effect due to their numbers, concentrated breeding habit, breeding habitat preferences and individual mass, and are capable of rapidly eroding surfaces down to bedrock. Although their impacts are amongst the most spectacular examples of zoogeomorphic activity, they are spatially restricted to a handful of large colonies in close proximity to suitable landing beaches. Rockhopper penguins have a far more limited effect as they favour rocky areas and do not breed in the concentrated coastal colonies.

Nest excavation activity by burrowing seabirds (petrels and prions) moves a significant amount of material and creates a distinctive topography in vegetated lowland areas of Marion Island. Each species has specific breeding habitat preferences in terms of topography and vegetation, and hence impacts vary spatially. Furthermore, burrow size and characteristics for each species differ, and hence the geomorphic impacts differ. Table 4.5 provides estimates of the amount of material moved, based on burrow volumes and published species densities.

The activities of sub-Antarctic fur seals result in a distinctive hummock topography. Seal activity results in the compaction of peat surfaces, as well as vegetation destruction in the immediate vicinity of landing beaches. In addition, fur seal activity results in modification of pond and stream morphology in coastal areas. In vegetated areas near stony or sandy beaches suitable for landing, elephant seals exert a significant, but localized, effect on the landscape through the creation of wallows. The great bulk of these animals flattens and compacts vegetation and peat bogs, creating local hollows which combine and deepen to form composite depressions. Local drainage is disrupted, and a distinctive topography of vegetated ridges with intervening depressions results.

Animal populations, and hence their geomorphic impacts, have experienced significant changes due to direct and indirect human intervention during the past 200 years. Commercial exploitation in the 1800s drove populations of fur and elephant seals to economic extinction. Although their original populations are unknown, relict elephant seal wallows across suitable areas of the island attest to a dramatic reduction in geomorphic impact caused by the humaninduced population crash. Fur seal populations are now recovering rapidly (and their impact is increasing), while initial recovery trends in elephant seal populations appear to be stabilizing. Indirectly, human actions have impacted on landscapes via alien fauna introductions. Feral cats were rapidly exterminating burrowing petrel populations (455 000 per year) in the 1970s and 1980s (Cooper \& Brown 1990). However, there has been an apparent recovery of populations since cats were eliminated, with a consequent increase in zoogeomorphic activity. 


\subsection{The record of Holocene climate change}

To date, much of the geomorphological research on Marion Island has focused on the terrestrial glacial and periglacial record as a proxy for Late Quaternary climate change. Paleoecological proxies from the coastal peat deposits have provided additional insights.

The glacial record of Holocene environmental change is fragmented with poor temporal constraints. Hall (1978) suggested a rapid deglaciation, now established to have started at 17-18 ka BP (Bianchi \& Gersonde 2004), but does not further consider Holocene glacial activity. Evidence for possible early Holocene glacial activity exists in the form of cirque basins at Snok and at the summit. The summit basins carried remnants of permanent ice bodies when first observed in 1954 and 1961, but have undergone rapid degradation over the past four decades (Sumner et al. 2004). A terminal moraine has been identified in one of the basins, with a small active nival rampart on its lee-side margin. However, the Marion Island cirques have not produced the much more detailed record of glacial advance and retreat such as reported for other sub-Antarctic Islands (e.g. Frenot et al. 1997).

Depending on the extent of glaciation of the Feldmark plateau, the development of the glacial cirque at Snok and the valley glacier at Watertunnel are temporally constrained by the island-wide last glaciation, which started its termination at $c .18 \mathrm{ka} \mathrm{BP}$ and the obtaining of Holocene temperatures following the Younger Dryas at c. $11 \mathrm{ka}$ BP (Bianchi \& Gersonde 2004). Summit glacial basins are likely to have persisted throughout most of the Holocene with the possible exception of the Holocene optimum (10-8 ka BP), but geomorphological evidence is likely to have been disturbed by Holocene volcanic activity. The present moraines at the summit and the nival rampart at Snok are best placed as indicative of Little Ice Age cooling with present day nival activity still maintaining ramparts at preferential snow accumulation sites. Current warming is also likely to increasingly marginalize these processes at the higher altitudes in the Island's interior.

In the interior of Marion Island, thermal erosion and subsidence of areas underlain by buried glacial ice has been recorded (Hedding 2006). The result is the manifestation of thermokarst-like features such as thaw slumps on scoria slopes and the creation of a unique undulating or "kettle" topography. These meltout features and processes represent distinct landscape-process responses to climate change which is unique in the southern African context.

The summer snow line has risen from 600-850 m a.s.l. in 1954 and 1961, to $950 \mathrm{~m}$ a.s.l. in 1971 and is currently above summit level (1 $200 \mathrm{~m}$ a.s.l.) (Sumner et al. 2004). The existence of a high altitude permanent snow cover in the late Holocene is also suggested by the absence of the large-scale relict periglacial landforms that occur at altitudes below $800 \mathrm{~m}$ a.s.l. (Hall 1981b, 1983b; Holness \& Boelhouwers 1998; Holness 2003b). This suggests that the stone-banked landforms above $800 \mathrm{~m}$ a.s.l. formed upon snowline retreat over 
the past decades. Relict periglacial landforms are present in all Last Glacial deposits associated with grey lava areas and coastal moraines and take the form of stone-banked lobes and terraces, vegetation-banked terraces, blockfields and blockstreams. The dominance of stone-banked forms and vertically sorted blockstream surfaces in till indicate frost heave and creep-dominated movement with solifluction-dominated unsorted terraces restricted to sites with impervious substrates or upslope moisture sources. The similar morphometry and depth of vertical sorting in relict coastal forms and recent forms above $800 \mathrm{~m}$ a.s.l. (0.2-0.7 m) suggests formation under conditions similar or somewhat more severe than recorded at present at $1000 \mathrm{~m}$ a.s.l. (mean annual ground surface temperature of $+1.2^{\circ} \mathrm{C}$ ). This indicates a temperature decrease of approximately $4-5.5^{\circ} \mathrm{C}$ from the present (Holness 2003b). Based on the closely corresponding summer sea surface temperature (Bianchi \& Gersonde 2004) and Dome C deuterium records (Jouzel et al. 2001), this places the main phase of Holocene periglacial activity to the period immediately following deglaciation, terminating at around $11 \mathrm{ka}$ BP when temperatures stabilized, enforced by the Holocene optimum. This interpretation is supported by the single-phase development of the landforms (Holness 2003b) and the steeper periglacial gradient in the relict record at Long Ridge (Holness \& Boelhouwers 1998). It also implies the Marion Island plateau surfaces (e.g. Long Ridge, Feldmark Plateau) to have been at least seasonally snow free upon deglaciation.

Holness (2003b) interpreted the absence of gelifluction-dominated landforms as an argument against the existence of early Holocene permafrost. However, the occurrence of differential frost heave and resulting sorting does not preclude gelifluction. Rather, given the temperature scenario estimated for the coastal landforms and the morphometrical data in Holness (2003b), permafrost is likely to have occurred in a temporally restricted and spatially narrow altitudinal zone between $c .400 \mathrm{~m}$ a.s.l. and the permanent snow and ice bodies that stabilized above $c .800 \mathrm{~m}$ a.s.l.

Paleoecological studies on the coastal peat deposits on the east side of the island have provided additional proxies of Holocene environmental change. Schalke \& Van Zinderen Bakker (1971) and Van Zinderen Bakker (1973) interpreted pollen spectra to indicate the transition of a low-altitude fjeldmark vegetation to the present dense grasses and phanerogram dominated vegetation during the amelioration period between deglaciation and the early Holocene. They note no marked vegetation or climate changes in the younger sections and obtain an oldest date of $9500 \mathrm{BP}$, with an extrapolated age, assuming constant deposition, at the base of the core of 16 ka BP (Schalke \& Van Zinderen Bakker 1971). Scott (1985) extended the pollen analysis from new peat cores, while Yeloff et al. (2007) provide a multi-proxy environmental reconstruction from a new core using pollen/non-pollen microfossil and macrofossil analyses, diatom, peat humification and tephra analyses. Both studies identify a vegetation succession in a landscape depression from barren fjeldmark to increasing Azorella selago abundance during initial peatland initiation. Ponds in 
the depressions are dominated by Ranunculus biternatus and Montia fontana. This is overgrown to develop a Agrostis magellanica and Acaena magellanica peatland. While the earliest example of this succession is recorded in the Macaroni Bay record to at least $10 \mathrm{ka} \mathrm{BP,} \mathrm{Scott} \mathrm{(1985)} \mathrm{and} \mathrm{Yeloff} \mathrm{et} \mathrm{al.} \mathrm{(2007)} \mathrm{demonstrated}$ this succession to have been initiated at different times during the Holocene at different locations. Based on the presence of tephra layers (Scott 1985; Yeloff et al., 2007) and association with peat slides, Scott (1985) suggested that disturbances created by volcanic activity and geomorphic activity can have a long-term impact on vegetation succession. The spatial extent of the tephra layers is unknown, limiting assessment of the scale of impact of these volcanic events on Holocene vegetation development. As such, the paleoecological record appears to largely indicate local successional changes with no direct evidence for Holocene changes in temperature or precipitation. Yeloff et al. (2007) do, however, suggest a Little Ice Age signal at c.630 cal BP associated with increased mire wetness, followed by drier conditions from 170 cal BP to present.

\subsection{Discussion and conclusions}

Research on Marion Island's volcanic tectonic setting and evolution has not yet been able to conclusively explain the topography of the older grey lava surfaces. Glacial geomorphological evidence indicates sufficiently thick ice to cover most grey lava surfaces with the possible exception of the elevated topographies of the Feldmark Plateau and a portion of Long Ridge. Arguments by Chevalier (1986), supported by recent remote sensing visualisations, suggest that the elevated position of such grey lava surfaces, already existed in preHolocene times. Furthermore, the qualitatively older appearance of surface materials and the existence of the largest periglacial landforms on the island suggest an ice free environment. Glacial moraines at Watertunnel and a cirque at Snok, in the Feldmark area, are, thus, likely to have resulted from Late Glacial or early Holocene stages of ice cover.

None of the arguments supporting glaciation, or the absence thereof, are unequivocal. The nature of the Feldmark regolith has not been investigated or dated and the presence of landforms there, that are used to suggest an absence of ice-cover, may simply be a manifestation of a post-glacial Holocene weathering and mass wasting regime resulting from island-wide aspect differences. Globally, there are many problems associated with linking the morphometry of periglacial slow mass wasting forms with the severity of ground climate. While Matsuoka (2001) established a basic correlation between riser height and depth of movement, the maximum depth of movement recorded in solifluction lobes did not exceed $60 \mathrm{~cm}$. Riser heights in excess of $3 \mathrm{~m}$ on Marion Island are, thus, likely the result of complex forms built from abundant local material supply (Boelhouwers et al. 2001), a local topography that allows deceleration (Matsuoka 2001), and abundant moisture supply (Holness 2003b). 
The Holocene record of periglacial landforms and its relation to Late Quaternary environmental change presents further conundrums. While a rich record of relict periglacial landforms has been described, chronological uncertainties limit a more detailed interpretation of the island's climate history. There is a clear need to establish a better geochronology of volcanic and geomorphological features to unravel the sequence of events that has resulted in the present-day physical landscape. Additional K-Ar dating and the application of cosmogenic exposure techniques provide new possibilities to answer these long-standing questions. New research documenting glacial geomorphological landforms (Hedding 2006; I. Meiklejohn, unpublished data) highlights the need for mapping to establish clearer spatial correlations of available proxies, using a combined approach of modern remote sensing and GPS-based field mapping.

The application of traditional empirical methods in slope process studies on Marion Island has highlighted the distinctiveness of maritime, mid-latitudinal periglacial environments (Holness 2001a; Boelhouwers et al. 2003). These relate to the dominance of diurnal soil frost processes and resulting high soil surface movement rates, the importance of wind and the stratified solifluction landforms. The uniform material properties within till and scoria, abundant moisture, and high cloud cover, result in strong correlations between patterned ground morphometry, process rates and environmental parameters. Periglacial soil creep on sub-Antarctic islands has clear interactions with vegetation dynamics (e.g. Selkirk 1998; Holness 2001a). This is particularly evident in the form of the slope-scale patterns of vegetation and micro-topography, e.g. turf-banked steps and crescent-shaped A. selago cushions (Holness 2001a; Boelhouwers et al. 2003). The nature of the interaction between sediment movement and vegetation dynamics however remains unclear.

An understanding is emerging regarding the responses of the sub-Antarctic periglacial environment to climate change. Degradation of landforms is clearly evident at the higher altitudes of Marion Island and is associated with the contemporary disappearance of the glacial ice bodies and permanent snow (Boelhouwers 2003; Sumner et al. 2004). The responses to current warming are likely to be non-linear and spatially differentiated. While warming results in a decrease in frost cycle frequency, reduced snow cover may enhance summit altitude frost cycles (Holness 2001a, 2003b). Reduced precipitation may offset the sustained latent heat effects due to abundant soil water at high altitude (Boelhouwers 2003) and enhance freeze-thaw efficacy. On the other hand, while moisture is not presently a constraint, it may become so in specific topographic settings. Reduced cloud cover, as reported by Smith (2002), may enhance evaporation and leads to a greater differentiation of the radiation balance by slope aspect, both at the slope and island scale (J. Boelhouwers, unpublished data). These considerations may indicate an increased spatial variability or patchiness in the occurrence and rates of soil movement processes. This is likely to impact the vegetation dynamics on the island. Given 
the existing empirical database, spatial modelling of the periglacial dynamics at an island scale now provides the most rational way to develop a quantitative understanding of the slope dynamics and its sensitivity and responses to changes in climate variables.

Areas of importance that have not received adequate attention are the soil development and succession in response to Holocene volcanic activity, the interaction between animals and landscape dynamics and terrestrial sediment and nutrient budgets. Each of these identifies important elements and interrelations between the abiotic and biotic components of the island's ecosystem. Their interface between earth scientific and biological disciplines may explain their historical absence from the research agenda, but, equally, highlights their importance in terms of developing an integrated understanding of the islands' terrestrial and off-shore geo-ecological system.

\subsection{References}

Benedict, J.B. 1976. Frost creep and gelifluction features: a review. Quaternary Research 6, 55-76.

Bertran, P., Hétu, B., Texier, J-P. \& Van Steijn, H. 1997. Fabric characteristics of subaerial slope deposits. Sedimentology 44, 1-16.

Bianchi, C. \& Gersonde, R. 2004. Climate evolution at the last deglaciation: the role of the Southern Ocean. Earth and Planetary Science Letters 228, 407-424.

Boelhouwers, J.C. 2003. Sensitivity and responses to climate change in the Subantarctic periglacial environment. In: Phillips, M., Springman, S-M. \& Arenson, L.U. (Eds.). Permafrost, Proceedings of the 8th International Conference on Permafrost. Zürich, Switzerland, pp. 67-71.

Boelhouwers, J.C., Holness, S. \& Sumner, P. 2000. Geomorphology of debris flows at Junior's Kop, Marion Island. Earth Surface Processes and Landforms 25, 341-352.

Boelhouwers, J.C., Holness, S. \& Sumner, P. 2003. The maritime Subantarctic: a distinct periglacial environment. Geomorphology 52, 39-55.
Boelhouwers, J.C., Holness, S.D., Sumner, P.D. \& Nel, W. 2001. Cryogenic Landforms and Processes on Marion Island. Final Report submitted to the South African Committee for Antarctic Research (SACAR), April 1996March 2001.

Campbell, I.B. 1981. Soil pattern of Campbell Island. New Zealand Fournal of Science 24, 111-135.

Chambers, M.J.G. 1966. Investigations of patterned ground at Signy Island, South Orkney Islands: II temperature regimes in the active layer. British Antarctic Survey Bulletin 10, 71-83.

Chevallier, L. 1986. Tectonics of Marion and Prince Edward Volcanoes (Indian Ocean): result of regional control and edifice dynamics. Tectonophysics 124, 155-175.

Chevallier, L., Verwoerd, W.J., Bova, P., Stettler, E., du Plessis, A., du Plessis, J.G., et al. 1992. Volcanological features and preliminary geophysical investigations on Marion Island. South African Fournal of Antarctic Research 22, 15-35. 
Cooper, J. \& Brown, G.R. 1990. Ornithological research at the subAntarctic Prince Edward Islands: a review of achievements. South African Journal of Antarctic Research 20, 40-57.

Crawford, R.J.M., Cooper, J., Dyer, B.M., Greyling, M.D., Klages, N.T.W., Ryan, P.G., et al. 2003. Populations of surface-nesting seabirds at Marion Island, 1994/95-2002/03. African Fournal of Marine Science 25, 427-440.

Francou, B. 1988. Eboulis stratifies dans les Hautes Andes Centrales du Perou. Zeitschrift für Geomorphologie 31, 47-76.

Francou, B. 1989. Stratogenesis in slope waste deposits submitted to freeze - thaw action : a new conception. Bulletin de l'Association Française pour l' etude du Quaternaire 4, 185-199.

Francou, B. 1990. Stratification mechanisms in slope deposits in high subequatorial Mountains. Permafrost and Periglacial Processes 1, 249-263.

Frenot, Y., Gloaguen, J.C., Van de Vijver, B. \& Beyens, J. 1997. Dating of some peat sediments and glacier fluctuations in the Kerguelen Islands. Committée Récherche l'Académie Scientifique Paris (Life Sciences) 320, 567-573.

Gribnitz, K.H., Kent, L.E. \& Dixon, R.D. 1986. Volcanic ash, ash soils and the inferred Quaternary climate of sub-Antarctic Marion Island. South African Fournal of Science 82, 629-635.

Hall, K. 1977. Evidence for Quaternary glaciation of Marion Island (subAntarctic) and some implications. In: Van Zinderen Bakker, E.M. (Ed.). Antarctic Glacial History and World Palaeoenvironment. Proceedings of a symposium held on 17th August 1977, during the 10th INQUA Congress, Birmingham, UK, pp.137-147.
Hall, K. 1978. Quaternary Glacial Geology of Marion Island. Ph.D. Thesis, University of the Orange Free State, South Africa.

Hall, K. 1979. Sorted stripes orientated by wind direction: some observations from sub-Antarctic Marion Island. Earth Surface Processes and Landforms $\mathbf{4}$, 281-289.

Hall, K. 1980. Late glacial ice cover and palaeotemperatures on sub-Antarctic Marion Island. Palaeogeography, Palaeoclimatology, Palaeoecology 29, 243-259.

Hall, K. 1981a. Quantitative analysis of till lithology on Marion Island. South African Fournal of Science 77, 86-90.

Hall, K. 1981b. Observations on the stone-banked lobes of Marion Island. South African Fournal of Science 77, 424.

Hall, K. 1982. Rapid deglaciation as an initiator of volcanic activity: an hypothesis. Earth Surface Processes and Landforms 7, 45-51.

Hall, K. 1983a. A reconstruction of the Quaternary ice cover on Marion Island. In: Oliver, R.L., James, P.R. \& Jago, J.B. (Eds.). Antarctic Earth Science. Australian Academy of Science, Canberra, pp. 461-464.

Hall, K. 1983b. Observations of some periglacial features and their palaeoenvironmental implications on sub-Antarctic islands Marion and Kerguelen. South African Fournal of Antarctic Research 13, 35-40.

Hall, K. 1983c. Sorted stripes on subAntarctic Kerguelen Island. Earth Surface Processes and Landforms $\mathbf{8}$, 115-124.

Hall, K. 1990a. Quaternary Glaciations in the Southern Ocean: Sector $0^{\circ}$ Long. - $180^{\circ}$ Long. Quaternary Science Reviews 9, 217-228. 
Hall, K. 1990b. Mechanical weathering rates on Signy Island, maritime Antarctic. Permafrost and Periglacial Processes 1, 61-67.

Hall, K. 2002. Review of present and Quaternary periglacial processes and landforms of the maritime and subAntarctic region. South African Fournal of Science 98, 71-81.

Hall, K. 2004. Quaternary glaciation of the sub-Antarctic Islands. In: Ehlers J. \& Gibbard P.I. (Eds.). Quaternary Glaciations - Extent and Chronology, Part III. Elsevier, Amsterdam, pp. 339-345.

Hall, K. \& Walton, D.W.H. 1992. Rock weathering, soil development and colonisation under a changing climate. Philosophical Transactions of the Royal Society of London B 338, 269-277.

Hall, K. \& Williams, A.J. 1981. Animals as agents of erosion at sub-Antarctic Marion Island. South African fournal of Antarctic Research 10/11, 18-24.

Hänel C. \& Chown, S.L. 1998. An Introductory Guide to the Marion and Prince Edward Island Special Nature Reserves. Department of Environmental Affairs and Tourism, Pretoria.

Harris, C. \& Davies, M.C.R. 2000. Gelifluction: observations from large-scale laboratorium simulations. Arctic, Antarctic and Alpine Research 32, 202-207.

Hedding, D.W. 2006. Geomorphology and geomorphological responses to climate change in the interior of sub-Antarctic Marion Island. M.Sc. Thesis, University of Pretoria, South Africa.

Heilbronn, T.D. \& Walton, D.W.H. 1984. The morphology of some periglacial features on South Georgia and their relationship to local environment. British Antarctic Survey Bulletin 64, 21-36.
Holness, S.D. 2001a. Periglacial slope processes, landforms and environment at Marion island, Maritime Subantarctic. Ph.D. Thesis, University of the Western Cape, South Africa.

Holness, S.D. 2001b. The orientation of sorted stripes in the maritime Subantarctic, Marion Island. Earth Surface Processes and Landforms $\mathbf{2 6}$, 77-89.

Holness, S.D. 2003a. Sorted circles in the maritime Subantarctic, Marion Island. Earth Surface Processes and Landforms 28, 337-347.

Holness, S.D. 2003b. The periglacial record of Holocene environmental change of Subantarctic Marion Island. Permafrost and Periglacial Processes 14, 69-74.

Holness, S.D. 2004. Sediment movement rates and processes on cinder cones in the maritime Subantarctic (Marion Island). Earth Surface Processes and Landforms 29, 91-103.

Holness, S.D. \& Boelhouwers, J. 1998. Periglacial indicators for Holocene climate change at Long Ridge, Marion Island, maritime subAntarctic. South African Fournal of Science 94, 399-403.

Jouzel, J., Masson, V., Cattani, O., Falourd, S., Stievenard, M., Stenni, B., et al. 2001. A new 27ky high resolution East Antarctic climate record. Geophysical Research Letters 28, 3199-3202.

Kent, L.E. \& Gribnitz, K.-H. 1983. Problematic Quaternary succession on Marion Island: volcanogenic or glacigenic? South African Fournal of Antarctic Research 13, 15-23.

Löffler, E. 1983. Macquarie island: a wind molded natural landscape in the Subantarctic. Polarforschung 53, 59-74. 
Mackay, J.R. \& Mathews, W.H. 1974. Movement of sorted stripes, the Cinder Cone, Garibaldi Park, B.C., Canada. Arctic and Alpine Research 6, 347-359.

Mahoney, J., le Roex, A.P., Peng, Z., Fisher, R.L. \& Natland, J.H. 1992. Southwestern limits of Indian Ocean ridge mantle and the origin of low $206 \mathrm{~Pb} / 204 \mathrm{~Pb}$ mid-ocean ridge basalt: Isotope systematics of the central Southwest Indian Ridge $\left(17^{\circ}-50^{\circ} \mathrm{E}\right)$. Journal of Geophysical Research 97, 19771-19790.

Matsuoka, N. 1996. Soil moisture variability in relation to diurnal frost heaving on Japanese high mountain slopes. Permafrost and Periglacial Processes 7, 139-151.

Matsuoka, N. 2001. Solifluction rates, processes and landforms: a global review. Earth-Science Reviewes $\mathbf{5 5}$, 107-134.

Matsuoka, N. 2005. Temporal and spatial variations in periglacial soil movements on alpine crest slopes. Earth Surface Processes and Landforms 30, 41-58.

McDougall, I. 1971. Geochronology. In: Van Zinderen Bakker, E.M., Winterbottom, J.M. \& Dyer, R.A. (Eds.). Marion and Prince Edward Islands. Report on the South African Biological and Geological Expedition 1965-1966. A.A. Balkema, Cape Town, pp. 72-77.

McDougall, I., Verwoerd, W. \& Chevalier, L. 2001. K-Ar geochronology of Marion Island, Southern Ocean. Geological Magazine 138, 1-17.

Meentemeyer, V. \& Zippin, J. 1981. Soil moisture and texture controls of selected paramenters of needle ice growth. Earth Surface Processes and Landforms 6, 113-125.
Meiklejohn, K.I. \& Hedding, D.W. 2005. Marion Island. In: Wunderman, R., Venzke, E. \& Mayberry, G. (Eds.). Bulletin of the Global Volcanism Network 30, 16.

Nel, W. 2001. A spatial inventory of glacial, periglacial and rapid mass movement forms on part of Marion Island: Implications for Quaternary environmental change. M.Sc. Dissertation, University of Pretoria, South Africa.

Nel, W., Holness, S. \& Meiklejohn, K.I. 2003. Observations on rapid mass movement and screes on subAntarctic Marion Island. South African fournal of Science 99, 177-181.

Pérez, F.L. 1993. Talus movement in the high equatorial Andes: a synthesis of ten years of data. Permafrost and Periglacial Processes 4, 199-215.

Schalke, H.J.W.G. \& Van Zinderen Bakker, E.M. 1971. History of the vegetation. In: Van Zinderen Bakker, E.M., Winterbottom, J.M. \& Dyer, R.A. (Eds.). Marion and Prince Edward Islands. Report on the South African Biological and Geological Expedition 1965-1966. A.A. Balkema, Cape Town, pp. 89-97.

Schramm, M. 1986. Burrow densities and nest site preferences of petrels (Procellariidae) at the Prince Edward Islands. Polar Biology 6, 63-70.

Schulze, B.R. 1971. The climate of Marion Island. In: Van Zinderen Bakker, E.M., Winterbottom, J.M. \& Dyer, R.A. (Eds.). Marion and Prince Edward Islands: Report on the South African Biological and Geological Expedition 1965-1966. A.A. Balkema, Cape Town, pp. 16-31.

Scott, L. 1985. Palynological indications of the Quaternary vegetation history of Marion Island (sub-Antarctic). fournal of Biogeography 12, 413-431. 
Selkirk, J.M. 1998. Active vegetationbanked terraces on Macquarie Island. Zeitschrift für Geomorphologie 42, 483-496.

Selkirk-Bell, J.M. 2000. Geomorphic processes and environmental change on Subantarctic Macquarie Island. Ph.D. Thesis, Macquarie University, Australia.

Smith, J. 1960. Cryoturbation data from South Georgia. Biuletyn Peryglacjalny 8, 72-76.

Smith, V.R. 2002. Climate change in the sub-Antarctic: an illustration from Marion Island. Climate Change 52, 345-357.

Sumner, P.D. 2004. Rock weathering rates on Subantarctic Marion Island. Arctic, Antarctic and Alpine Research 36, 123-127.

Sumner, P.D. \& Meiklejohn, K.I. 2004. On the development of autochthonous blockfields in the grey basalts of Subantarctic Marion Island. Polar Geography 28, 20-32.

Sumner, P., Meiklejohn, I., Boelhouwers, J. \& Hedding, D. 2004: Climate change melts Marion's snow and ice. South African Fournal of Science 100, 395-398.

Taylor, B.W. 1955a. Terrace formation on Macquarie Island. Fournal of Ecology 43, 133-137.

Taylor, B.W. 1955b. The flora, vegetation and soils of Macquarie Island. Australian National Antarctic Research Expedition Reports B11, 84-192.
Thorn, C.E. 1979. Bedrock freeze-thaw weathering regime in an alpine environment, Colorado Front Range. Earth Surface Processes and Landforms $\mathbf{4}$, 211-228.

Van Zinderen Bakker, E.M. 1973. The second South African biological expedition to Marion Island, 1971-1972. South African Fournal of Antartic Research 3, 60-63.

Van Zinderen Bakker, E.M., Winterbottom, J.M. \& Dyer, R.A. (Eds.) 1971. Marion and Prince Edward Islands. Report on the South African Biological and Geological Expedition 1965-1966. A.A. Balkema, Cape Town.

Verwoerd, W.J. 1971. Geology. In: Van Zinderen Bakker, E.M., Winterbottom, J.M. \& Dyer, R.A. (Eds.). Marion and Prince Edward Islands. Report on the South African Biological and Geological Expedition 1965-1966. A.A. Balkema, Cape Town, pp. 40-53.

Verwoerd, W.J., Russell, S. \& Berruti, A. 1981. 1980 volcanic eruption reported on Marion Island. Earth and Planetary Science Letters 54, 397-422.

Wunderman, R., Venzke, E. \& Mayberry, G. (Eds.) 2004. Bulletin of the Global Volcanism Network 29(9), Smithsonian National Museum of Natural History, Washington DC.

Yeloff, D., Mauquoy, D., Barber, K., Way, S., Van Geel, B. \& Turney, C.S.M. 2007. Volcanic ash deposition and long-term vegetation change on Subantarctic Marion Island. Arctic, Antarctic and Alpine Research 39, 500-511. 